\title{
Pharmacological Agents Targeting Thromboinflammation in COVID-19: Review and Implications for Future Research
}

Behnood Bikdeli ${ }^{1,2,3, *}$ Mahesh V. Madhavan 1,3,* Aakriti Gupta ${ }^{1,2,3}$ David Jimenez ${ }^{4,5}$ John R. Burton ${ }^{1}$ Caroline Der Nigoghossian ${ }^{1}$ Taylor Chuich ${ }^{1}$ Shayan Nabavi Nouri ${ }^{1}$ Isaac Dreyfus ${ }^{1}$ Elissa Driggin ${ }^{1}$ Sanjum Sethi ${ }^{1}$ Kartik Sehgal $^{6,7}$ Saurav Chatterjee ${ }^{8}$ Walter Ageno ${ }^{9}$ Mohammad Madjid $^{10}$ Yutao Guo ${ }^{11,12 @ ~ L i a n g ~ V . ~ T a n g ~}{ }^{13}$ Yu Hu$^{13}$ Laurent Bertoletti ${ }^{14}$ Jay Giri ${ }^{15,16,17}$ Mary Cushman ${ }^{18}$ Isabelle Quéré ${ }^{19}$ Evangelos P. Dimakakos ${ }^{20} \quad$ C. Michael Gibson ${ }^{6,7}$ Giuseppe Lippi ${ }^{21}$ Emmanuel J. Favaloro 22,23 Jawed Fareed ${ }^{24}$ Alfonso J. Tafur ${ }^{25,26}$ Dominic P. Francese $^{3}$ Jaya Batra ${ }^{1}$ Anna Falanga ${ }^{27}$ Kevin J. Clerkin ${ }^{1}$ Nir Uriel ${ }^{1}$ Ajay Kirtane ${ }^{1,3}$ Claire McLintock $^{28}$ Beverley J. Hunt ${ }^{29}$ Alex C. Spyropoulos ${ }^{30}$ Geoffrey D. Barnes ${ }^{31,32}$ John W. Eikelboom ${ }^{33}$ Ido Weinberg 6,34 Sam Schulman ${ }^{35,36,37}$ Marc Carrier ${ }^{38}$ Gregory Piazza ${ }^{6,39}$ Joshua A. Beckman ${ }^{40}$ Martin B. Leon ${ }^{1,3}$ Gregg W. Stone ${ }^{3,41}$ Stephan Rosenkranz ${ }^{42}$ Samuel Z. Goldhaber ${ }^{6,39}$ Sahil A. Parikh ${ }^{1,3}$ Manuel Monreal ${ }^{43}$ Harlan M. Krumholz $2,44,45$ Stavros V. Konstantinides ${ }^{460}$ Jeffrey I. Weitz ${ }^{36,37}$ Gregory Y. H. Lip ${ }^{12,47}$ The Global COVID-19 Thrombosis Collaborative Group

${ }^{1}$ New York-Presbyterian Hospital/Columbia University Irving Medical Center, New York, New York, United States

${ }^{2}$ Center for Outcomes Research and Evaluation (CORE), Yale School of Medicine, New Haven, Connecticut, United States

${ }^{3}$ Clinical Trials Center, Cardiovascular Research Foundation, New York, New York, United States

${ }^{4}$ Respiratory Department, Hospital Ramón y Cajal, Madrid, Spain

${ }^{5}$ Medicine Department, Universidad de Alcalá (IRYCIS), CIBER de Enfermedades Respiratorias (CIBERES), Madrid, Spain

${ }^{6}$ Harvard Medical School, Boston, Massachusetts, United States

7 Beth Israel Deaconess Medical Center, Boston, Massachusetts, United States

8 North Shore and Long Island Jewish University Hospitals, Queens, New York, United States

${ }^{9}$ Department of Medicine and Surgery, University of Insubria, Varese, Italy

10 McGovern Medical School, The University of Texas Health Science Center at Houston, Houston, Texas, United States

${ }^{11}$ Department of Cardiology, Chinese PLA General Hospital, Beijing, China

12 Liverpool Centre for Cardiovascular Science, University of Liverpool and Liverpool Heart and Chest Hospital, Liverpool, United Kingdom

13 Institute of Hematology, Union Hospital, Tongji Medical College, Huazhong University of Science and Technology, Wuhan, China

${ }^{14}$ Department of “Médecine Vasculaire et Thérapeutique," CIC 1408, INNOVTE, CHU de St-Etienne and INSERM UMR1059, Université Jean-Monnet, Saint-Etienne, France

${ }^{15}$ Cardiovascular Division, Hospital of the University of Pennsylvania, Philadelphia, Pennsylvania, United States

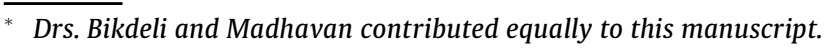

Address for correspondence Behnood Bikdeli, MD, MS, New YorkPresbyterian Hospital/Columbia University Irving Medical Center, 622 West 168th St, PH 3-347, New York, NY 10032, United States (e-mail: bb2813@cumc.columbia.edu, Behnood.bikdeli@yale.edu).

Mahesh Vasantha Madhavan, MD, NewYork-Presbyterian Hospital/Columbia University Irving Medical Center, 622 West 168th St, PH 3-347, New York, NY 10032, United States (e-mail: mvm2122@cumc.columbia.edu).

16 Penn Cardiovascular Outcomes, Quality, and Evaluative Research Center, Leonard Davis Institute of Health Economics, University of Pennsylvania, Philadelphia, Pennsylvania, United States

${ }^{17}$ Corporal Michael J. Crescenz VA Medical Center, Philadelphia, Pennsylvania, United States

${ }^{18}$ Larner College of Medicine, University of Vermont, Burlington, Vermont, United States

${ }^{19}$ Department of Vascular Medicine, University of Montpellier, Montpellier CHU, InnoVTE F-CRIN Network, Montpellier, France

${ }^{20}$ Oncology Unit GPP, Sotiria General Hospital, Athens School of Medicine, Athens, Greece

${ }^{21}$ Laboratory of Clinical Chemistry and Hematology, University Hospital of Verona, Verona, Italy

${ }^{22}$ Laboratory Haematology, Institute of Clinical Pathology and Medical Research (ICPMR), NSW Health Pathology, Westmead Hospital, Westmead, NSW, Australia

${ }^{23}$ Sydney Centres for Thrombosis and Haemostasis, Westmead, NSW, Australia

${ }^{24}$ Loyola University Medical Center, Chicago, Illinois, United States

(c) 2020 Georg Thieme Verlag KG Stuttgart - New York
DOI https://doi.org/ 10.1055/s-0040-1713152. ISSN 0340-6245. 
25 Pritzker School of Medicine at the University of Chicago, Chicago, Illinois, United States

26 Division of Vascular Medicine, Department of Medicine, NorthShore University HealthSystem, Skokie, Illinois, United States

27 Department of Immunohematology and Transfusion Medicine, Hospital Papa Giovanni XXIII, University of Milan Bicocca, Bergamo, Italy

28 Auckland City Hospital, Auckland, New Zealand

29 St Thomas' Hospital, London, United Kingdom

30 The Donald and Barbara Zucker School of Medicine at Hofstra/Northwell, New York, New York, United States

31 Institute for Healthcare Policy and Innovation, University of Michigan, Ann Arbor, Michigan, United States

32 Frankel Cardiovascular Center, University of Michigan, Ann Arbor, Michigan, United States

33 Population Health Research Institute, McMaster University and Hamilton Health Sciences, Hamilton, Ontario, Canada

34 Massachusetts General Hospital, Boston, Massachusetts, United States

${ }^{35}$ Department of Obstetrics and Gynecology, I.M. Sechenov First Moscow State Medical University, Moscow, Russia

Thromb Haemost 2020;120:1004-1024.
${ }^{36}$ McMaster University, Hamilton, Ontario, Canada

${ }^{37}$ Thrombosis \& Atherosclerosis Research Institute, Hamilton, Ontario, Canada

38 The Ottawa Hospital Research Institute, Ottawa, Ontario, Canada

${ }^{39}$ Brigham and Women's Hospital, Boston, Massachusetts, United States

${ }^{40}$ Vanderbilt University School of Medicine, Nashville, Tennessee, United States

${ }^{41}$ The Zena and Michael A. Wiener Cardiovascular Institute, Icahn School of Medicine at Mount Sinai, New York, New York, United States

${ }^{42}$ Department of Cardiology, Cologne Cardiovascular Research Center (CCRC), Heart Center at the University of Cologne, University of Cologne, Cologne, Germany

${ }^{43}$ Department of Internal Medicine, Hospital Universitari Germans Trials I Pujol, Universidad Católica de Murcia, Barcelona, Spain

${ }^{44}$ Department of Health Policy and Administration, Yale School of Public Health, New Haven, Connecticut, United States

${ }^{45}$ Section of Cardiovascular Medicine, Department of Internal Medicie, Yale School of Medicine, New Haven, Connecticut, United States

${ }^{46}$ Center for Thrombosis and Hemostasis, Johannes Gutenberg University of Mainz, Mainz, Germany

${ }^{47}$ Department of Clinical Medicine, Aalborg Thrombosis Research Unit, Aalborg University, Aalborg, Denmark

\section{Abstract}

\section{Keywords}

- coronavirus disease 2019

- thrombosis

- inflammation

- fibrinolytic therapy

- anticoagulation

- immunomodulator

- antithrombin

- thrombomodulin
Coronavirus disease 2019 (COVID-19), currently a worldwide pandemic, is a viral illness caused by the severe acute respiratory syndrome coronavirus 2 (SARS-CoV-2). The suspected contribution of thrombotic events to morbidity and mortality in COVID-19 patients has prompted a search for novel potential options for preventing COVID-19associated thrombotic disease. In this article by the Global COVID-19 Thrombosis Collaborative Group, we describe novel dosing approaches for commonly used antithrombotic agents (especially heparin-based regimens) and the potential use of less widely used antithrombotic drugs in the absence of confirmed thrombosis. Although these therapies may have direct antithrombotic effects, other mechanisms of action, including anti-inflammatory or antiviral effects, have been postulated. Based on survey results from this group of authors, we suggest research priorities for specific agents and subgroups of patients with COVID-19. Further, we review other agents, including immunomodulators, that may have antithrombotic properties. It is our hope that the present document will encourage and stimulate future prospective studies and randomized trials to study the safety, efficacy, and optimal use of these agents for prevention or management of thrombosis in COVID-19.

\section{Introduction}

The severe acute respiratory syndrome coronavirus 2 (SARS-CoV-2) has resulted in a global pandemic., ${ }^{1,2}$ SARS-CoV-2, which is responsible for coronavirus disease 2019 (COVID-19), can cause pneumonia and acute respiratory distress syndrome (ARDS) as well as several extrapulmonary manifestations. These include cardiovascular, hematologic, and thrombotic sequelae due to direct and indirect effects of the viral illness. ${ }^{3-5}$ Indeed, the limited data available on thrombotic complications in patients with COVID-19 suggest that rates of venous thromboembolic events may be as high as 25 to
$30 \%$, particularly in critically ill, mechanically ventilated patients. ${ }^{6-8}$ Thrombotic complications also include stroke, acute limb ischemia, and acute coronary syndromes. ${ }^{9-11}$

Limited data are available to determine the antithrombotic therapy to improve outcomes in patients with COVID19 who do not have confirmed evidence of thrombosis. The optimal dose and agent for thromboprophylaxis remain unknown. Conservative management has merit based on historical data pertaining to critically ill medical patients ${ }^{12}$ as well as for COVID-19-specific escalation of treatment. ${ }^{13}$ For interim decision-making, consensus-based guidance has been provided by some groups, ${ }^{14-18}$ including the Global 
COVID-19 Thrombosis Collaborative Group ${ }^{5}$ (-Table 1). However, unlike other extensively studied illnesses such as sepsis, ${ }^{19}$ a comprehensive assessment of potential options for prevention of thrombosis in various subgroups of patients with COVID-19 has not to date been proposed.

In this article, prepared by the Global COVID-19 Thrombosis Collaborative Group, we summarize potential therapeutic options for prevention of thrombosis in COVID-19 patients in the absence of confirmed thrombotic events. Our focus is on novel approaches to dosing commonly used antithrombotic agents (heparin-based regimens and direct oral anticoagulants [DOACs]), considerations for empiric use of less widely used antithrombotic drugs such as danaparoid, and the potential applications of antiplatelet agents. In addition to the direct antithrombotic effects, other mechanisms of action-including anti-inflammatory or antiviral effects-have been postulated. ${ }^{20,21}$ Finally, we discuss other therapies, such as immunomodulators, that may have antithrombotic properties. The goal is not to provide immediately actionable management recommendations (as high-quality data to reliably inform such guidance in patients with COVID-19 are lacking), but rather to summarize potential treatment options and their advantages and limitations for ongoing and future investigations. We outline research priorities for these agents across the relevant clinical subgroups.

\section{Methodological Considerations}

To provide a thorough assessment for the rationale and potential advantages and limitations of various antithrombotic agents, subcommittees from the collaborative drafted the sections focused on specific agents, and these sections were then reviewed and revised by the entire group. The colead authors searched MEDLINE (with PubMed interface) to ensure that no other high-quality clinical study was missed (date of last search: May 5, 2020).

For research priority setting, a survey was sent to the group of coauthors who were asked to rate the overall priority for investigating each of the discussed agents and to identify the care setting wherein the investigation was most reasonable (outpatients with COVID-19, inpatients on the wards, critically ill patients in the intensive care unit [ICU], or patients posthospital discharge).

\section{Investigational Strategies Targeting Thromboinflammation in COVID-19}

In the subsequent sections, we describe various investigational strategies for anticoagulants, antiplatelet agents, hemostatic modulating agents, and immunomodulators that may have potential for further investigation for patients with COVID-19 (- Table 2; - Fig. 1). In addition, a summary of the survey results for research priorities with these agents is provided in -Table 3 and -Figs. 2 and 3.

\section{Anticoagulants}

\section{Unfractionated Heparin and Low-Molecular-Weight Heparins}

Unfractionated heparin and low-molecular-weight heparins (LMWHs) are the most frequently administered parenteral anticoagulants. ${ }^{22}$ In addition to their antithrombotic activity, they have postulated anti-inflammatory and antiviral

Table 1 Suggested considerations for prevention and management of thrombosis among hospitalized patients with COVID-19

Risk stratification for VTE should be performed for all inpatients with COVID-19. In the absence of contraindications, the vast majority of inpatients, including all patients with severe COVID-19 who are critically ill should receive prophylactic anticoagulation

The optimal intensity of anticoagulation in patients with COVID-19 remains unknown. Although prophylactic dosing is most widely used, higher intensity of anticoagulation (including intermediate-dose and full-therapeutic anticoagulation) is being used by many clinicians/institutions. Additional studies are required to identify the optimal regimen in various patient groups with COVID-19

For hospitalized patients with COVID-19 who require therapeutic anticoagulation (for prior indications including AF, VTE, mechanical valves, or new incident events such as new VTE or type I myocardial infarction), presence or absence of DIC, and hepatic and renal function should be considered when determining the appropriate choice of anticoagulant agent and dose ${ }^{a}$

Hemostatic derangements, including elevated D-dimer levels, are common among inpatients with COVID-19. The majority of a consensus panel did not find sufficient evidence for routine screening for VTE (e.g., bilateral lower extremity ultrasound, or computed tomography pulmonary angiography) for hospitalized patients with COVID-19. However, a high clinical index of suspicion for VTE should be maintained and appropriate diagnostic tests should be pursued in case of signs or symptoms for DVT (including unexplained lower extremity pain or swelling) or PE (including unexplained chest pain, unexplained right ventricular dysfunction, or hypoxemia disproportionate to the pulmonary infiltrates)

Risk stratification for VTE should be done for hospitalized patients at the time of discharge. Extended pharmacological prophylaxis (up to $45 \mathrm{~d}$ ) should be considered for patients at high risk of VTE who do not have a high risk of bleeding

Drug-drug interactions should be considered between investigational COVID-19 therapies and antithrombotic agents

Abbreviations: AF, atrial fibrillation; COVID-19, coronavirus disease 2019; DIC, disseminated intravascular coagulation; DVT, deep venous thrombosis; PE, pulmonary embolism; VTE, venous thromboembolism.

${ }^{a}$ More detailed recommendations are provided in a separate manuscript. ${ }^{5}$ 
Therapeutic Targets for COVID-19-Associated Thrombosis Bikdeli et al. 1007

Table 2 Empiric or investigational use of agents with antithrombotic properties in COVID-19

\begin{tabular}{|c|c|c|c|}
\hline & $\begin{array}{l}\text { Postulated mechanism(s) or } \\
\text { data from other ARDS series }\end{array}$ & $\begin{array}{l}\text { Clinical evidence in patients } \\
\text { with COVID-19 }\end{array}$ & Comment \\
\hline \multicolumn{4}{|l|}{ Anticoagulants } \\
\hline $\begin{array}{l}\text { Intermediate-dose heparin } \\
\text { (UFH or LMWH) }\end{array}$ & $\begin{array}{l}\text { - Heparin-based products } \\
\text { have anti-inflammatory and } \\
\text { antiviral properties } \\
\text { - Meta-analysis of } 9 \text { trials in- } \\
\text { cluding } 465 \text { patients sug- } \\
\text { gested that adjunctive } \\
\text { LMWH was associated with } \\
\text { significantly lower rates of } \\
\text { mortality at } 28 \text {-d in patients } \\
\text { with ARDS (RR } 0.63,95 \% \mathrm{Cl} \\
0.41-0.96) .182 \text { Subgroup } \\
\text { analysis demonstrated } \\
\text { greater effect on oxygen- } \\
\text { ation in patients who re- } \\
\text { ceived } \geq 5,000 \text { U/d of LMWH } \\
\text { - In vitro data suggests hep- } \\
\text { arin may prevent virus-in- } \\
\text { duced cell death of human } \\
\text { progenitor cells exposed to } \\
\text { Zika virus }{ }^{183} \\
\text { - In vitro data suggests hep- } \\
\text { arin exposure may reduce } \\
\text { infectivity of SARS-CoV }{ }^{184}\end{array}$ & $\begin{array}{l}\text { - Among a group of } 449 \\
\text { patients admitted for COVID- } \\
19 \text { in Wuhan, } 99 \text { ( } 22 \%) \text { re- } \\
\text { ceived intermediate-dose } \\
\text { UFH or LMWH }{ }^{185} \\
\text { - No significant differences in } \\
28-d \text { mortality was noted in } \\
\text { patients who received hepa- } \\
\text { rin-based products versus } \\
\text { those that did not receive } \\
\text { heparin ( } 30.3 \% \text { vs. } 29.7 \% \text {, } \\
p=0.91), \text { but anticoagula- } \\
\text { tion in patients with } \\
\text { Ddimer }>3 \mu \text { g/mL was asso- } \\
\text { ciated with lower } 28-d \text { mor- } \\
\text { tality }(32.8 \% \text { vs. } 52.4 \% \text {, } \\
p=0.017)\end{array}$ & $\begin{array}{l}\text { - There is limited evidence, } \\
\text { suggesting that heparin may } \\
\text { interact with the spike S1 } \\
\text { protein receptor domain of } \\
\text { SARS-CoV-2 } 21,186\end{array}$ \\
\hline $\begin{array}{l}\text { Therapeutic heparin (UFH } \\
\text { or LMWH) }\end{array}$ & $\begin{array}{l}\text { - As above with intermediate- } \\
\text { dose heparin } \\
\text { - Empiric heparin reduced } \\
\text { rates of thrombotic events } \\
\text { without increased bleeding } \\
\text { complications in H1N1 } \\
\text { pneumonia26 }\end{array}$ & $\begin{array}{l}\text { - In a retrospective analysis, } \\
\text { use of therapeutic anticoa- } \\
\text { gulation was associated with } \\
\text { lower mortality (adjusted HR } \\
\text { of } 0.86 \text { per day, } 95 \% \text { confi- } \\
\text { dence interval } 0.82-0.89 \text {, } \\
p<0.001 \text { ) without increased } \\
\text { bleeding. The indication for } \\
\text { anticoagulation, or the type } \\
\text { of treatment were not de- } \\
\text { scribed. Sufficient informa- } \\
\text { tion was not provided about } \\
\text { the comorbidity profile of the } \\
\text { patients (e.g., contraindica- } \\
\text { tions to anticoagulation) }\end{array}$ & - As above \\
\hline Danaparoid & $\begin{array}{l}\text { - Danaparoid has been shown } \\
\text { to reduce cytokine levels and } \\
\text { attenuate thrombosis in ani- } \\
\text { mal models } 44,45 \\
\text { - It can be administered sys- } \\
\text { temically or nebulized } \\
\text { - Nebulized danaparoid can } \\
\text { attenuate coagulation activi- } \\
\text { ty in the lungs and systemi- } \\
\text { cally as well as reduce levels } \\
\text { of pulmonary inflammation. } \\
\text { Animal models of lung injury } \\
\text { suggest improved survival } \\
\text { with its administration } 46\end{array}$ & $\begin{array}{l}\text { - No current evidence for } \\
\text { danaparoid in COVID-19 }\end{array}$ & $\begin{array}{l}\text { - Heparan sulfate moiety in } \\
\text { danaparoid may have antivi- } \\
\text { ral actions and may restore } \\
\text { heparan deficit on vascular } \\
\text { endothelium } \\
\text { - Given minimal effect on } \\
\text { platelets } 40 \text { and ability to be } \\
\text { used in patients with severe } \\
\text { renal failure, } 188 \text { danaparoid } \\
\text { may have the potential for } \\
\text { use for thromboprophylaxis } \\
\text { in patients with COVID-19 }\end{array}$ \\
\hline DOACs & $\begin{array}{l}\text { - DOACs have demonstrated } \\
\text { mixed results with regards to } \\
\text { inpatient and postdischarge } \\
\text { prophylaxis for VTE } 54,57 \\
\text { - In patients at high risk for } \\
\text { VTE and low risk for bleeding } \\
\text { (including those with severe } \\
\text { infection), betrixaban and }\end{array}$ & $\begin{array}{l}\text { - No current evidence for } \\
\text { DOACs in COVID-19 } \\
\text { - There is an ongoing clinical } \\
\text { trial assessing DOACs with } \\
\text { DAPT, statins, and PPIs in } \\
\text { patients with COVID-19 and } \\
\text { suspected acute coronary } \\
\text { syndrome (NCT04333407) }\end{array}$ & $\begin{array}{l}\text { - Considerations when ad- } \\
\text { ministering DOACs in } \\
\text { patients with COVID-19 in- } \\
\text { clude longer half-life, avail- } \\
\text { ability of reversal agents, } \\
\text { renal clearance, and drug- } \\
\text { drug interactions with }\end{array}$ \\
\hline
\end{tabular}

(Continued) 
Table 2 (Continued)

\begin{tabular}{|c|c|c|c|}
\hline & $\begin{array}{l}\text { Postulated mechanism(s) or } \\
\text { data from other ARDS series }\end{array}$ & $\begin{array}{l}\text { Clinical evidence in patients } \\
\text { with COVID-19 }\end{array}$ & Comment \\
\hline & $\begin{array}{l}\text { rivaroxaban showed a net } \\
\text { clinical benefit for inpatient } \\
\text { thromboprophylaxis and for } \\
\text { extended thromboprophy- } \\
\text { laxis posthospital } \\
\text { discharge } 54,56,58\end{array}$ & & $\begin{array}{l}\text { investigational therapies for } \\
\text { COVID- } 19^{5}\end{array}$ \\
\hline \multicolumn{4}{|l|}{ Fibrinolytic agents } \\
\hline $\begin{array}{l}\text { Fibrinolytic therapy (in- } \\
\text { cluding tPA) }\end{array}$ & $\begin{array}{l}\text { - There is some evidence to } \\
\text { suggest microthrombi in the } \\
\text { setting of ARDS and critically } \\
\text { ill patients } 189 \\
\text { - Urokinase and tissue-type } \\
\text { plasminogen activator have } \\
\text { been shown to be protective } \\
\text { in murine models and to re- } \\
\text { duce the risk of ARDS in por- } \\
\text { cine models }\end{array}$ & $\begin{array}{l}\text { - Systemic fibrinolytic thera- } \\
\text { py has been used off-label in } \\
\text { ill patients with ARDS sec- } \\
\text { ondary to COVID-19 with } \\
\text { transient improvement in } \\
\text { oxygenation and ventilatory } \\
\text { requirement. } \\
\text { term benefits have been long- } \\
\text { established }\end{array}$ & $\begin{array}{l}\text { - Further evaluation of the } \\
\text { role of fibrinolytics should be } \\
\text { explored } \\
\text { - Further prospectively col- } \\
\text { lected data in this space is } \\
\text { needed } \\
\text { - Established risks include } \\
\text { major bleeding events (in- } \\
\text { cluding intracranial hemor- } \\
\text { rhage); however, further } \\
\text { understanding of the risk for } \\
\text { diffuse alveolar hemorrhage } \\
\text { is needed }\end{array}$ \\
\hline \multicolumn{4}{|l|}{ Antiplatelets } \\
\hline Aspirin & $\begin{array}{l}\text { - Aspirin is associated with } \\
\text { diminished incidence of } \\
\text { ARDS and improved survival } \\
\text { in the setting of acute lung } \\
\text { injury in animal models and } \\
\text { observational human stud- } \\
\text { ies }{ }^{94-99} \\
\text { - While prospective analyses } \\
\text { have suggested reduced } \\
\text { mortality when used in the } \\
\text { prehospital and ICU set- } \\
\text { ting } 97,98 \text {, these findings were } \\
\text { not validated in a random- } \\
\text { ized trial which evaluated its } \\
\text { use for preventing ARDS }\end{array}$ & $\begin{array}{l}\text { - No current evidence for as- } \\
\text { pirin in COVID-19 } \\
\text { - There is an ongoing clinical } \\
\text { trial assessing DOACs with } \\
\text { DAPT, statins, and PPIs in } \\
\text { patients with COVID-19 and } \\
\text { suspected acute coronary } \\
\text { syndrome (NCT04333407) }\end{array}$ & \\
\hline $\begin{array}{l}\text { P2Y12 receptor } \\
\text { antagonists }\end{array}$ & $\begin{array}{l}\text { - Ticagrelor administration } \\
\text { within } 48 \mathrm{~h} \text { of pneumonia } \\
\text { diagnosis was associated } \\
\text { with reduced circulating } \\
\text { platelet-leukocyte aggre- } \\
\text { gates, interleukin-6 levels, } \\
\text { and improved oxygen } \\
\text { requirements and lung func- } \\
\text { tion in the randomized XAN- } \\
\text { THIPPE trial }\end{array}$ & $\begin{array}{l}\text { - No current evidence for } \\
\text { P2Y12 receptor inhibition in } \\
\text { COVID-19 } \\
\text { - There is an ongoing clinical } \\
\text { trial assessing DOACs with } \\
\text { DAPT, statins, and PPIs in } \\
\text { patients with COVID-19 and } \\
\text { suspected acute coronary } \\
\text { syndrome (NCT04333407) }\end{array}$ & $\begin{array}{l}\text { - Ticagrelor-associated dys- } \\
\text { pnea should be considered }\end{array}$ \\
\hline Dipyridamole & $\begin{array}{l}\text { - The antithrombotic effect } \\
\text { of dipyridamole is thought to } \\
\text { be via phosphodiesterase in- } \\
\text { hibition } \\
\text { - Animal models suggest po- } \\
\text { tential antiviral activity in the } \\
\text { setting of influenza } 113\end{array}$ & $\begin{array}{l}\text { - A small trial randomized } 22 \\
\text { patients to dipyridamole } \\
\text { ( } 150 \text { mg orally three times a } \\
\text { day) vs. routine control in } \\
\text { which the treatment group } \\
\text { had higher hospitalization } \\
\text { discharge rates compared } \\
\text { with the control group } \\
\text { (58.4\% vs. } 20.0 \% \text { ), increased } \\
\text { platelet counts, stabilization } \\
\text { of D-dimer levels, with trends } \\
\text { to suggest faster recovery }{ }^{190}\end{array}$ & \\
\hline
\end{tabular}


Table 2 (Continued)

\begin{tabular}{|c|c|c|c|}
\hline & $\begin{array}{l}\text { Postulated mechanism(s) or } \\
\text { data from other ARDS series }\end{array}$ & $\begin{array}{l}\text { Clinical evidence in patients } \\
\text { with COVID-19 }\end{array}$ & Comment \\
\hline \multicolumn{4}{|l|}{ Anti-inflammatory } \\
\hline Statins & $\begin{array}{l}\text { - Anti-inflammatory effect: } \\
\text { Regulation of MYD } 88 \text { levels } \\
\text { that mitigate NF-kB activa- } \\
\text { tion } 167 \\
\text { - Anticoagulant and Anti- } \\
\text { platelet effects: Downregu- } \\
\text { lation of TF, upregulation of } \\
\text { thrombomodulin, and inhi- } \\
\text { bition of TXA }{ }_{2}^{171}\end{array}$ & $\begin{array}{l}\text { - No current evidence for } \\
\text { statin use in COVID-19 } \\
\text { - Several ongoing studies } \\
\text { evaluating the use of statins } \\
\text { in COVID-19 (NCT04348695, } \\
\text { NCT04333407, and } \\
\text { NCT04343001) }\end{array}$ & \\
\hline Immunomodulators & $\begin{array}{l}\text { - Murine models suggest that } \\
\text { complement inhibition may } \\
\text { reduce severity of SARS-CoV } \\
\text { and MERS-CoV } 20\end{array}$ & $\begin{array}{l}\text { - Complement inhibition and } \\
\text { JAK inhibitors have been } \\
\text { suggested as potential ther- } \\
\text { apies for COVID-19 } 20 \\
\text { - JAK inhibitors have been } \\
\text { shown to have in vitro activ- } \\
\text { ity against SARS-CoV-2 }\end{array}$ & \\
\hline Activated protein $\mathrm{C}$ & $\begin{array}{l}\text { - Antithrombotic effect of } \\
\text { activated protein C in early } \\
\text { stage of sepsis-induced DIC } \\
\text { - Activated protein C may } \\
\text { reduce the damage caused } \\
\text { by ischemia/reperfusion in- } \\
\text { jury, gastrointestinal inflam- } \\
\text { mation, sepsis, and Ebola } \\
\text { virus infection } 130 \\
\text { - Anti-inflammatory and } \\
\text { cytoprotective effects } \\
\text { through PAR1-mediated bi- } \\
\text { ased signaling } 191 \\
\text { - Recombinant-activated } \\
\text { protein C may attenuate } \\
\text { systemic coagulopathy and } \\
\text { pulmonary coagulopathy, } \\
\text { but randomized controlled } \\
\text { data of activated protein C } \\
\text { for infectious or inflammato- } \\
\text { ry ARDS did not improve } \\
\text { alveolocapillary permeability } \\
\text { nor clinical outcomes }{ }^{134}\end{array}$ & $\begin{array}{l}\text { - In critically ill COVID-19 } \\
\text { patients, } 4 / 11 \text { individuals } \\
\text { had a protein C level mod- } \\
\text { estly lower than the average } \\
\text { reference values }{ }^{119}\end{array}$ & $\begin{array}{l}\text { - Further study needed to } \\
\text { determine if low levels of } \\
\text { protein } C \text { are common and } \\
\text { whether activated protein C } \\
\text { or } 3 \text { K3A-APC have any benefit } \\
\text { in patients with COVID-19 }\end{array}$ \\
\hline Corticosteroids & $\begin{array}{l}\text { - Glucocorticoids modulate } \\
\text { inflammatory response and } \\
\text { coagulation factors (VWF, fi- } \\
\text { brinogen, plasminogen acti- } \\
\text { vator inhibitor-1) } 15 T \\
\text { - Evidence in prior triggers } \\
\text { for ARDS, including SARS- } \\
\text { CoV and MERS-CoV, is } \\
\text { inconclusive. } 145-147\end{array}$ & $\begin{array}{l}\text { - Retrospective analysis in } \\
\text { COVID-19 patients with } \\
\text { ARDS suggested reduced risk } \\
\text { of death with methylpred- } \\
\text { nisolone treatment (HR } 0.38 \text {, } \\
95 \% \mathrm{Cl} 0.20-0.72, p<0.001 \text { ) } \\
144 \\
\text { - Data from a paper currently } \\
\text { on a preprint server did not } \\
\text { show any association be- } \\
\text { tween glucocorticoid use and } \\
28-d \text { mortality in critically ill } \\
\text { patients } 192\end{array}$ & \\
\hline Hydroxychloroquine & $\begin{array}{l}\text { - Prior studies suggesting } \\
\text { mild antiplatelet effects and } \\
\text { possible reversal of throm- } \\
\text { bogenic properties of anti- } \\
\text { phospholipid antibod- } \\
\text { ies } 154,158 \\
\text { - No specific studies available } \\
\text { in ARDS }\end{array}$ & $\begin{array}{l}\text { - No current evidence for the } \\
\text { association between use of } \\
\text { hydroxychloroquine and } \\
\text { thrombosis in COVID-19 }\end{array}$ & $\begin{array}{l}\text { - Data from a small case se- } \\
\text { ries suggests antiphospholi- } \\
\text { pid antibodies may play a role } \\
\text { in development of thrombo- } \\
\text { sis in patients with COVID- } \\
19^{193} \text { Further data are need- } \\
\text { ed to assess whether }\end{array}$ \\
\hline
\end{tabular}


Table 2 (Continued)

\begin{tabular}{|c|c|c|c|}
\hline & $\begin{array}{l}\text { Postulated mechanism(s) or } \\
\text { data from other ARDS series }\end{array}$ & $\begin{array}{l}\text { Clinical evidence in patients } \\
\text { with COVID-19 }\end{array}$ & Comment \\
\hline & & & $\begin{array}{l}\text { hydroxychloroquine may } \\
\text { have a benefit in COVID-19 }\end{array}$ \\
\hline \multicolumn{4}{|l|}{ Other } \\
\hline Antithrombin & $\begin{array}{l}\text { - Reduced levels in SARS } \\
\text { patients who developed } \\
\text { osteonecrosis } 194 \\
\text { - Inflammation and coagul- } \\
\text { opathy modulation in lung } \\
\text { injury animal models }{ }^{122-124} \\
\text { - Increased bleeding in criti- } \\
\text { cally ill trial data126 }\end{array}$ & $\begin{array}{l}\text { - When compared with } 40 \\
\text { healthy controls, patients } \\
\text { with COVID-19 had signifi- } \\
\text { cantly lower antithrombin } \\
\text { levels }\end{array}$ & $\begin{array}{l}\text { - Mechanisms for lower anti- } \\
\text { thrombin in such patients is } \\
\text { unclear, and this may poten- } \\
\text { tially be mediated by con- } \\
\text { sumption versus reduced } \\
\text { synthesis by the liver }\end{array}$ \\
\hline Thrombomodulin & $\begin{array}{l}\text { - Anticoagulant and anti-in- } \\
\text { flammatory effects mediated } \\
\text { through activated protein C- } \\
\text { dependent and independent } \\
\text { protein C mechanisms } \\
\text { - A systematic review sug- } \\
\text { gested that recombinant } \\
\text { thrombomodulin in patients } \\
\text { with sepsis-induced coagul- } \\
\text { opathy was associated with } \\
\text { reduced rates of mortality }{ }^{129}\end{array}$ & $\begin{array}{l}\text { - No current evidence for } \\
\text { thrombomodulin in COVID- } \\
19\end{array}$ & $\begin{array}{l}\text { - Given that thrombocyto- } \\
\text { penia is not very common in } \\
\text { COVID-19, it remains unclear } \\
\text { if recombinant thrombomo- } \\
\text { dulin would have benefit in } \\
\text { this patient population }\end{array}$ \\
\hline Contact activation system & $\begin{array}{l}\text { - Nonhuman primate models } \\
\text { of bacterial sepsis suggest } \\
\text { that inhibition of the contact } \\
\text { activation system can reduce } \\
\text { levels of inflammatory cyto- } \\
\text { kines, microvascular throm- } \\
\text { bosis, and potentially } \\
\text { contribute to improved } \\
\text { survival }\end{array}$ & $\begin{array}{l}\text { - No current evidence for } \\
\text { modulation of contact acti- } \\
\text { vation system in COVID-19 }\end{array}$ & \\
\hline
\end{tabular}

Abbreviations: ARDS, acute respiratory distress syndrome; Cl, confidence interval; CVA, cerebrovascular accident; DAPT, dual antiplatelet therapy; DIC, disseminated intravascular coagulation; DOAC, direct oral anticoagulant; HR, hazard ratio; ICU, intensive care unit; JAK, Janus kinase; LMWH, low-molecular-weight heparin; MERS-CoV, Middle Eastern respiratory syndrome coronavirus; NF-kB, nuclear factor kappa B; PAR1, proteaseactivated receptor 1; PE, pulmonary embolism; RR, relative risk; SARS-CoV, severe acute respiratory syndrome coronavirus; STEMI, ST-segment elevation myocardial infarction; TF, tissue factor; tPA, tissue-type plasminogen activator; $T X A_{2}$, thromboxane $A_{2}$; UFH, unfractionated heparin; VTE, venous thromboembolism; vWF: von Willebrand factor.

properties. Their anti-inflammatory properties may occur through selectin blockade, inhibition of bradykinin and thrombin generation, and binding of inflammatory cytokines. ${ }^{23,24}$ Heparins may also possess antiviral properties. For example, heparin may attenuate viral interaction with the angiotensin-converting enzyme 2 (ACE2) receptor by binding SARS-CoV-2 spike protein. ${ }^{25}$

The use of empiric heparin anticoagulation in patients with H1N1 ARDS was associated with reduced risk of thrombotic events without an increase in bleeding complications. ${ }^{26}$ With this consideration and the concern for breakthrough rates of thrombotic events despite prophylactic anticoagulation, ${ }^{7}$ several randomized trials evaluating varying intensities of heparin-based anticoagulation, ranging from prophylactic, or weight-adjusted prophylactic dose treatment to intermediate to full-dose therapy are underway (NCT04345848, NCT04344756, NCT04373707, NCT04359277, NCT04367831, NCT04362085, NCT04377997). Additionally, several institutions have implemented protocols to initiate therapeutic anti- coagulation empirically, utilizing risk stratification based on an individual's thrombotic and bleeding risk. ${ }^{27,28}$ Future prospective studies are needed to evaluate the use of these strategies on thrombotic and bleeding complications.

One potential challenge in the use of unfractionated heparin is the utility of the activated partial thromboplastin time (aPTT) for monitoring heparin. In patients with COVID19 , besides the intensity of heparin-based regimens, substantial heterogeneity in the aPTT response may be driven by high levels of factor VIII and fibrinogen, or the presence of a lupus anticoagulant. ${ }^{29,30}$ Consequently, anti-factor Xa levels may need to be measured to ensure that a therapeutic heparin level is achieved. ${ }^{31}$

Trials of inhaled heparin for treatment of COVID-19 are being planned to disrupt SARS-CoV-2 and its ACE2 receptor interaction. Docking of the virus to host cells is mediated by the interaction between the spike $(S)$ protein and heparan sulfate chains of proteoglycans. This facilitates further binding of SARS-CoV-2 to its cell-surface 
A

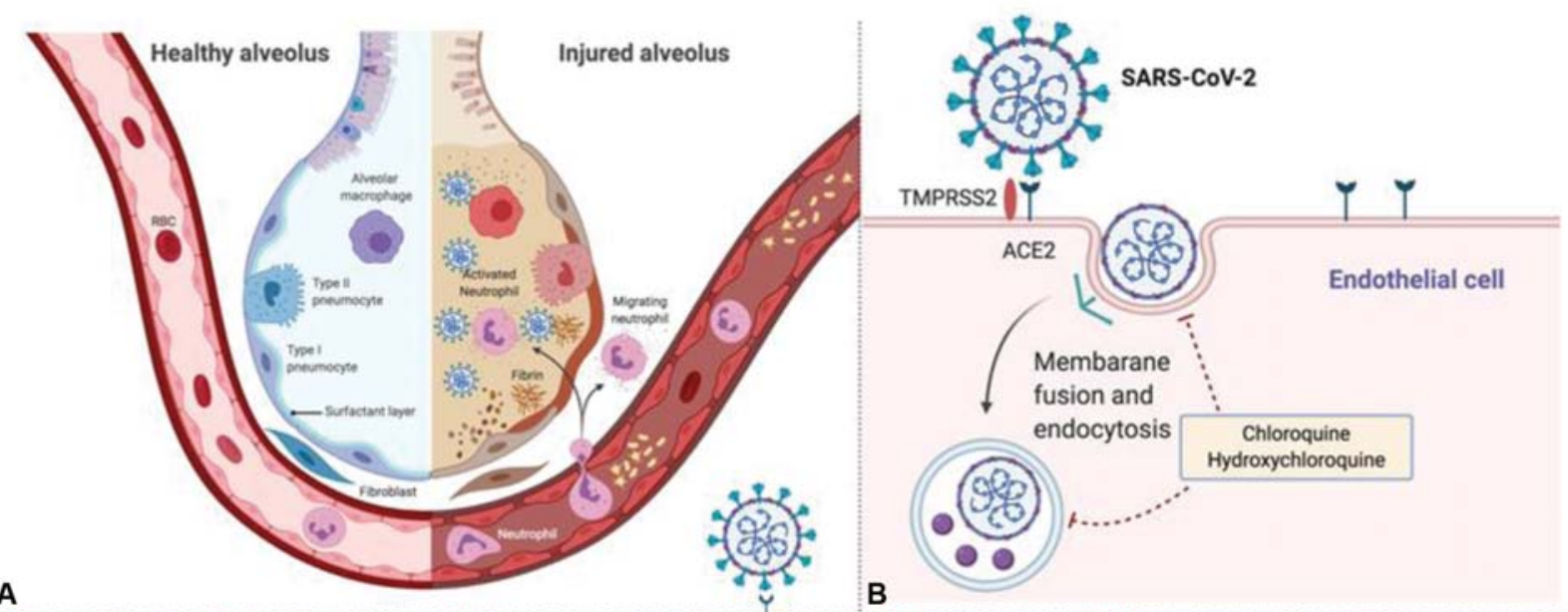

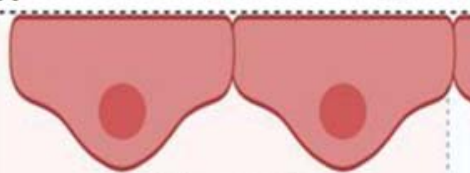

Inflammation

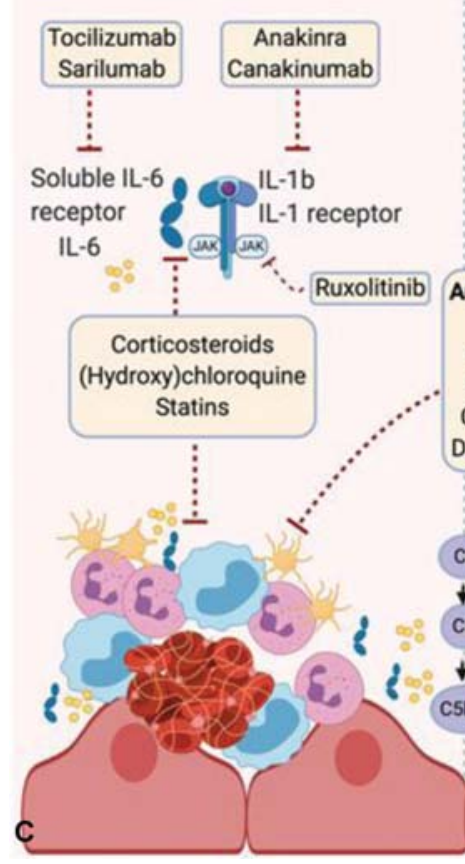

B

Fig. 1 Postulated mechanism of novel treatment options for management of thrombosis in COVID-19. (A) Viral alveolar injury and inflammation, including fibrin deposition. (B) Viral entry into the endothelial cells and the possible protective effect of hydroxychloroquine. (C) Potential mechanism of effect of various agents with antithrombotic properties for mitigating thrombotic complications in COVID-19. COVID19, coronavirus disease 2019; tPA, tissue-type plasminogen activator.

receptor, ACE2, via the surface unit (S1) of its $S$ protein. $^{32-34}$ It is known that heparin can displace surface proteoglycans, and prevent SARS-CoV-2 entry into human cells. ${ }^{21,35}$ Drug-drug interactions between COVD-19 investigational therapies and antithrombotic agents should be also considered. - Fig. 3 provides a graphical summary of potential interactions.

\section{Danaparoid}

Danaparoid (a mixture of sulfated glycosaminoglycans including heparan sulfate, dermatan sulfate, and chondroitin sulfate) attenuates thrombin generation by catalyzing the inhibition of factor Xa by antithrombin and by inhibition of thrombin by antithrombin and heparin cofactor II. ${ }^{36}$ Currently, danaparoid is predominantly used in patients with heparin-induced thrombocytopenia in several countries other than the United States.

ARDS is associated with dysregulated inflammation and coagulation. ${ }^{5,20,37}$ Patients with ARDS have an increased risk of venous thromboembolism (VTE) as well as thrombocytopenia, ${ }^{38}$ renal failure, and bleeding. ${ }^{39}$ Because of its safety profile in patients with heparin-induced thrombocytopenia, 
Table 3 Research priorities for use of antithrombotic agents in patients with COVID-19 without diagnosed thrombosis ${ }^{\mathrm{a}}$

\begin{tabular}{|c|c|c|}
\hline Agent & $\begin{array}{l}\text { Research priority, } \\
\text { mean (SEM) }{ }^{\mathrm{b}}\end{array}$ & Patient subgroups of highest relevance ${ }^{c}$ \\
\hline $\begin{array}{l}\text { Intermediate dose heparin (unfractionated or } \\
\text { LMWH) }\end{array}$ & $7.82(0.39)$ & $\begin{array}{l}\text { Hospitalized ICU patients }(62.5 \%) \\
\text { Hospitalized ward patients }(47.5 \%)\end{array}$ \\
\hline $\begin{array}{l}\text { Therapeutic dose heparin (unfractionated or } \\
\text { LMWH) }\end{array}$ & $7.53(0.40)$ & Hospitalized ICU patients (82.5\%) \\
\hline Danaparoid & $4.50(0.40)$ & $\begin{array}{l}\text { Hospitalized ward patients (51.3\%) } \\
\text { Hospitalized ICU patients (35.9\%) }\end{array}$ \\
\hline $\begin{array}{l}\text { Other parenteral anticoagulants (bivalirudin, } \\
\text { argatroban, fondaparinux) }\end{array}$ & $4.89(0.38)$ & $\begin{array}{l}\text { Hospitalized ICU patients }(56.4 \%) \\
\text { Hospitalized ward patients }(38.5 \%)\end{array}$ \\
\hline Vitamin-K antagonists & $3.08(0.37)$ & $\begin{array}{l}\text { Postdischarge patients (50.0\%) } \\
\text { Non-hospitalized patients (28.9\%) }\end{array}$ \\
\hline $\begin{array}{l}\text { Direct oral anticoagulants (dabigatran, rivaroxa- } \\
\text { ban, apixaban, edoxaban, betrixaban) }\end{array}$ & $7.95(0.29)$ & $\begin{array}{l}\text { Postdischarge patients }(80.0 \%) \\
\text { Nonhospitalized patients (20.0\%) }\end{array}$ \\
\hline Sulodexide & $4.50(0.46)$ & $\begin{array}{l}\text { Hospitalized ward patients (35.3\%) } \\
\text { Postdischarge patients (23.5\%) }\end{array}$ \\
\hline Fibrinolytic therapy & $6.20(0.40)$ & Hospitalized ICU patients (86.8\%) \\
\hline Aspirin & $5.87(0.39)$ & $\begin{array}{l}\text { Nonhospitalized patients (46.2\%) } \\
\text { Postdischarge patients (25.6\%) }\end{array}$ \\
\hline P2Y12 receptor antagonists & $5.15(0.40)$ & $\begin{array}{l}\text { Nonhospitalized patients ( } 34.2 \%) \\
\text { Hospitalized ward patients }(34.2 \%)\end{array}$ \\
\hline Dipyridamole & $4.00(0.38)$ & $\begin{array}{l}\text { Hospitalized ward patients (44.4\%) } \\
\text { Nonhospitalized patients (36.1\%) }\end{array}$ \\
\hline Dual-antiplatelet therapy & $4.77(0.44)$ & $\begin{array}{l}\text { Hospitalized ward patients (35.3\%) } \\
\text { Postdischarge patients ( } 24.3 \%)\end{array}$ \\
\hline Antithrombin & $4.05(0.42)$ & $\begin{array}{l}\text { Hospitalized ICU patients }(56.8 \%) \\
\text { Hospitalized ward patients }(32.4 \%)\end{array}$ \\
\hline Thrombomodulin & $4.43(0.47)$ & $\begin{array}{l}\text { Hospitalized ICU patients }(60.6 \%) \\
\text { Hospitalized ward patients }(30.3 \%)\end{array}$ \\
\hline Activated protein $\mathrm{C}$ & $3.97(0.41)$ & $\begin{array}{l}\text { Hospitalized ICU patients }(79.4 \%) \\
\text { Hospitalized ward patients }(17.6 \%)\end{array}$ \\
\hline
\end{tabular}

Abbreviations: COVID-19, coronavirus disease 2019; ICU, intensive care unit; LMWH, low-molecular-weight heparin; SEM, standard error of the mean. aBased on a survey of the Global COVID-19 Thrombosis Collaborative Group. For practical purposes, it was not possible to include all investigational agents.

${ }^{\mathrm{b}}$ From 1 to 10,10 being the highest priority.

'Up to two categories each with > 15\% vote, not mutually exclusive.

its minor effects on platelet function ${ }^{40}$ (particularly in sepsis), and potential for management of disseminated intravascular coagulation (DIC), ${ }^{36,41}$ danaparoid appears to be an attractive option for research in critically ill patients with COVID-19. Importantly, however, no reversal agent is available in the setting of bleeding complications.

Thrombi have been noted in the pulmonary arteries and vessels of other organs including the liver and kidneys in patients having died of COVID-19. The presence of these in situ thrombi raises the possibility that widespread endothelial activation in COVID-19 triggers thrombosis. ${ }^{42,43}$ In animal models of sepsis, danaparoid reduces cytokine levels and attenuates thrombosis. ${ }^{44,45}$ Intra-alveolar deposits of fibrin and activated leukocytes also contribute to the respiratory failure in patients with COVID-19 pneumonia. Danaparoid can be nebulized and has been shown to attenuate pulmonary coagulopathy, systemic coagulation, pulmonary inflammation, and improve survival in a lung injury model. ${ }^{46}$
Nebulized danaparoid administration may concentrate its effect on the lungs and decrease the risk of systemic adverse reactions. Although danaparoid is being empirically used in some centers, no published report or registered clinical trials exist for its use in COVID-19.

\section{Other Parenteral Anticoagulants}

Parenteral anticoagulants such as bivalirudin, argatroban, and fondaparinux have been studied in management of patients with acute coronary syndromes, VTE, and heparin-induced thrombocytopenia. ${ }^{47,48}$ However, these agents are more expensive than unfractionated heparin or LMWH, and there are limited data about their use in COVID-19.

\section{Vitamin-K Antagonists}

Vitamin-K antagonists (VKAs), including warfarin, function by inhibiting vitamin $\mathrm{K}$ epoxide reductase, which results in 


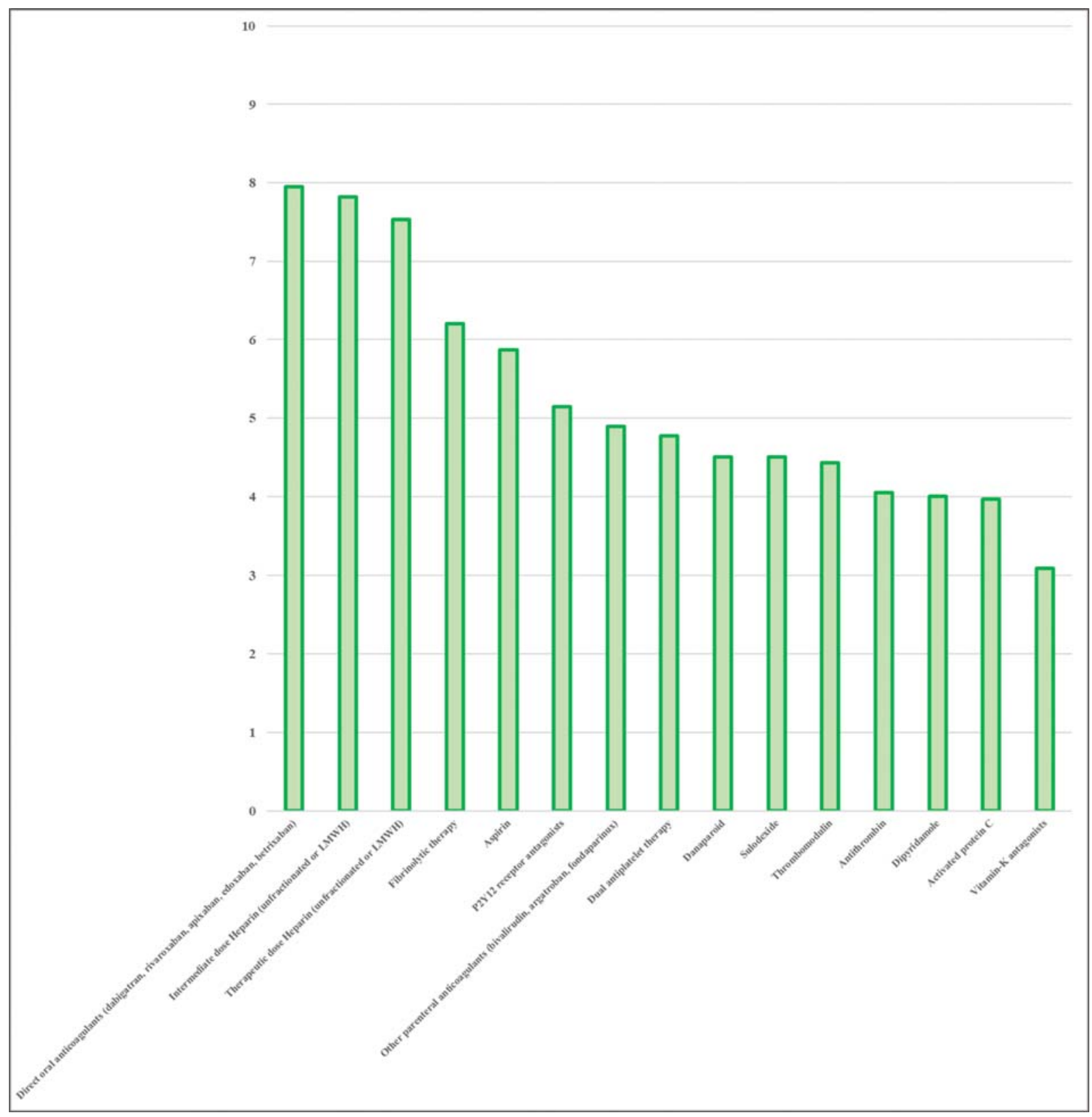

Fig. 2 Bar graph representing the research priorities as voted by the coauthors.

the prevention of the recycling of vitamin K epoxide back to its active form. ${ }^{49}$ The active form of vitamin $\mathrm{K}$ is essential for synthesis of clotting factors in the coagulation cascade (e.g., II, VII, IX, and X) and anticoagulant factors (proteins C and S), ${ }^{49}$ and so VKAs result in reduction of these factors. These drugs are used for treatment of established thrombotic events (e.g., deep venous thrombosis or pulmonary embolism) or for prophylaxis in patients with specific indications (e.g., atrial fibrillation and prosthetic mechanical heart valves). However, in the course of COVID-19 there are several challenges with use of VKAs, including drugdrug interactions, and need for international normalized ratio monitoring, as described previously. ${ }^{5}$ There are currently no active studies evaluating the use of VKAs in COVID-19.

\section{Direct Oral Anticoagulants}

Beyond their anticoagulant effects, DOACs, especially factor Xa inhibitors, may exert anti-inflammatory effects in COVID$19 .^{50}$ As has been demonstrated with rivaroxaban, DOACs can prevent arterial and venous thrombosis in patients with history of acute coronary syndrome, ${ }^{51}$ stable atherosclerotic vascular disease, ${ }^{52}$ or peripheral artery disease undergoing revascularization. ${ }^{53}$ Rivaroxaban and betrixaban reduce the risk of VTE in medically ill patients. ${ }^{54-56}$ As such, there is interest in administering DOACs to patients with severe COVID-19. These benefits should be weighed against the increased risk of bleeding events.

DOACs offer the potential for in-hospital and posthospital VTE prophylaxis. Results of studies with DOACs for extended prophylaxis in medically ill patients without COVID-19 have 


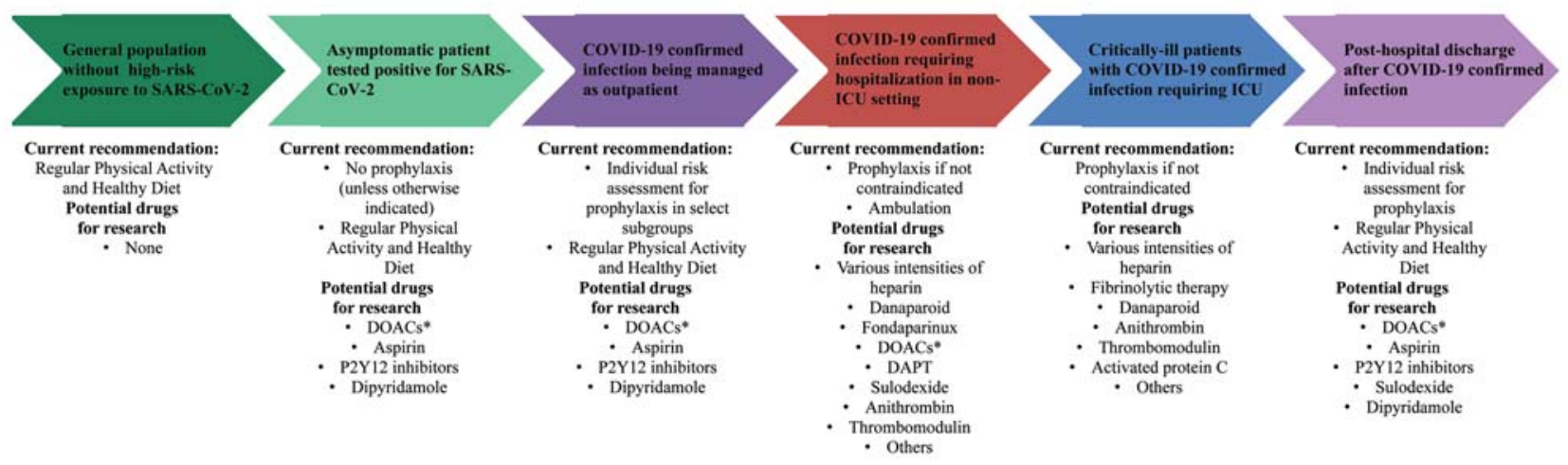

*Standard or low dose. COVID-19: coronavirus disease 2019. DAPT: dual antiplatelet therapy. DOAC: direct oral anticoagulant.

Fig. 3 Considerations for research investigations of pharmacotherapy for prevention of thrombosis or disease progression in patients with SARS-CoV-2 infection.

been mixed. ${ }^{54,57}$ However, recent investigations in patients who are at high risk for VTE and low risk for bleeding (including those with severe infection) have demonstrated a net clinical benefit, especially for extended thromboprophylaxis posthospital discharge with betrixaban or rivaroxaban. $^{54,58}$ There is currently one registered clinical trial (C19-ACS) assessing low-dose rivaroxaban along with dualantiplatelet therapy, statins, and a proton-pump inhibitor in patients with COVID-19 and a suspected acute coronary syndrome (NCT04333407).

A few centers have integrated DOACs into VTE prophylaxis algorithms for both in-hospital and postdischarge care. ${ }^{28}$ However, concerns remain about DOAC use in patients with COVID-19-associated complications, including its renal clearance and acute renal insufficiency, need for invasive procedures (e.g., dialysis access), extracorporeal membrane oxygenation, and difficultly in administering reversal agents. ${ }^{59,60}$ Finally, drug-drug interactions need to be considered when using DOACs with some investigational COVID19 therapies (see - Fig. 4). ${ }^{5}$ A recent small study showed increased absorption with high drug levels of DOACs in patients with COVID-19 who received antiviral agents. ${ }^{61}$ DOACs may offer an attractive option to prevent thromboembolic events in the prehospitalization period for high-risk patient groups with COVID-19, such as those with underlying cardiovascular disease or high VTE risk factors. There is at least one planned study with rivaroxaban underway in outpatients with COVID-19 (Prevent HD).

In patients with high suspicious for VTE, diagnosis should be sought when possible. For empiric treatment of select patients in whom presumed VTE events cannot be confirmed during the hospitalization period, for logistical reasons, use of DOACs upon hospital discharge offers additional convenience. ${ }^{62}$ Challenges with this approach include the uncertainty in the diagnosis of VTE, and that delayed VTE imaging may not have sufficiently high negative predictive value to exclude an earlier event. Some COVID-19 patients will not be candidates for DOACs, such as those with severe renal dysfunction, mechanical heart valves, and antiphospholipid syndrome, or those taking antiviral or immunomodulatory medications that may be associated with drug-drug interactions, and poor medication adherence.

\section{Sulodexide}

Sulodexide is an orally administered purified glycosaminoglycan consisting of heparan sulfate $(80 \%)$ and dermatan sulfate. ${ }^{63}$ It exerts antithrombotic properties through reduction of fibrinogen ${ }^{64,65}$ and plasminogen activator inhibitor- 1 (PAI-1 $)^{64,66}$ and is thought to have anti-inflammatory properties. $^{65,67,68}$ In a recent systematic review of randomized trials across a variety of cardiovascular indications, use of sulodexide compared with control was associated with reduced risk of VTE, myocardial infarction, cardiovascular mortality, and all-cause mortality. ${ }^{69}$ Despite the potential interest, limited data exist about the safety and efficacy of sulodexide in patients with COVID-19 and there are currently no registered trials for sulodexide in these patients.

\section{Fibrinolytic (Thrombolytic) Agents}

\section{Systemic Fibrinolytic Therapy}

Systemic fibrinolytic (thrombolytic) therapy is approved for management of ST-segment elevation myocardial infarction, ischemic stroke, and high-risk pulmonary embolism. Off-label use has been reported for the treatment of a small number of severely ill patients with ARDS secondary to COVID-19. ${ }^{70-72}$ While empiric use of fibrinolytic agents is not based on solid clinical evidence and confers significant bleeding risk, there is precedent for its use in ARDS. As with other causes of ARDS, fibrin-rich hyaline membranes have been reported in lung biopsy specimens from patients with COVID-19. ${ }^{73}$ Additionally, D-dimer, prothrombin time, and fibrinogen levels may all be increased in COVID-19 patients with significant lung involvement, ${ }^{74}$ suggesting derangement of coagulation. The presence of microthrombi in the pulmonary microcirculation has been implicated as a possible mechanism for clinical deterioration. $^{75}$

Fibrinolytic agents such as urokinase and tissue-type plasminogen activator have reduced the risk of ARDS in porcine models. ${ }^{76}$ Similarly, lung-protective findings have 


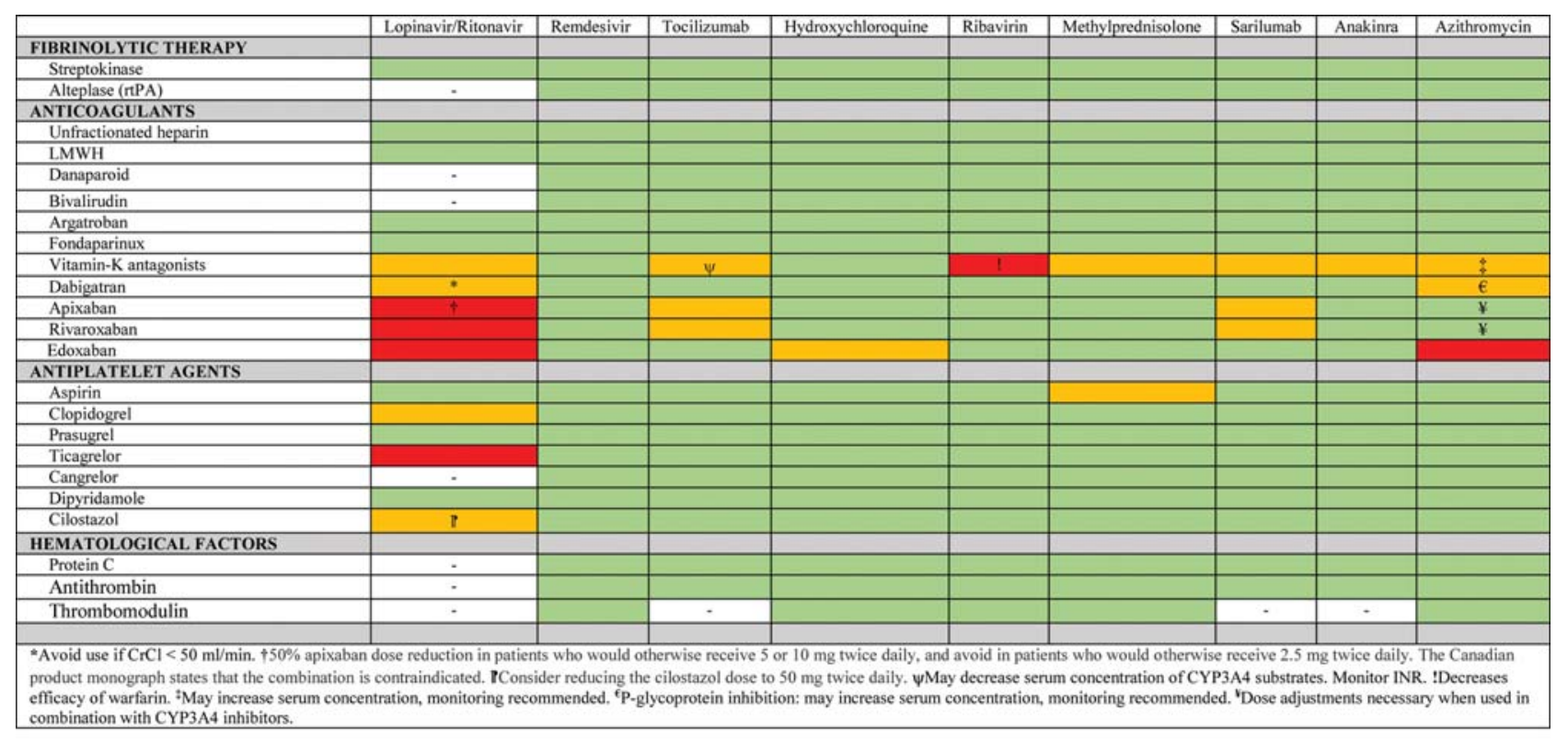

\begin{tabular}{|c|c|c|c|}
\hline Fiaure guide & & & \\
\hline $\begin{array}{l}\text { Low risk of } \\
\text { interaction }\end{array}$ & $\begin{array}{l}\text { Risk for mild-or moderate interaction } \\
\text { (see legend for details) }\end{array}$ & $\begin{array}{l}\text { High risk of serious interaction. Need dose } \\
\text { adjustment or do not co-administer }\end{array}$ & $\begin{array}{l}\text { No data } \\
\text { available }\end{array}$ \\
\hline
\end{tabular}

Fig. 4 Graphical summary of drug-drug interactions between coronavirus disease 2019 (COVD-19) investigational therapies and antithrombotic agents.

been noted in murine models. ${ }^{77} \mathrm{~A}$ meta-analysis of preclinical studies corroborated these findings in various animal models. ${ }^{78}$ Anecdotal reports have noted improvement in oxygenation and ventilation parameters. ${ }^{79} \mathrm{~A}$ recent small study $(n=60)$ study found improvement in surrogate parameters of ventilation and a reduction in ICU mortality in patients with severe non-COVID-19-related ARDS treated with inhaled streptokinase. ${ }^{80}$

The bleeding risks of fibrinolysis must be balanced against these preclinical data and small human series. Systemic fibrinolysis has been associated with a 1 to $3 \%$ rate of intracranial hemorrhage and notable risk of other forms of major bleeding across a wide span of acute diseases. ${ }^{81-83}$ Additionally, there is concern for diffuse alveolar hemorrhage after fibrinolysis, though reports of this complication have yet to be reported. Prior studies have suggested fibrinolytic agents such as alteplase can be associated with prolonged hypofibrinogenemia. ${ }^{84}$

Based on the present evidence utilization of fibrinolysis for COVID-19-associated ARDS, even when severe, cannot uniformly be recommended given its unknown risk-benefit ratio. However, investigational use of fibrinolytic agents in carefully selected patients may be considered. A phase $2 \mathrm{a}$ randomized trial is underway to test the hypothesis whether systemic tissue-type plasminogen activator results in an improvement of respiratory function/oxygenation and reduction in mortality (NCT04357730). Further, inhaled fibrinolytic agents are an interesting option, potentially limiting systemic complications. ${ }^{85}$ Assessment of their safety and efficacy requires further investigation (NCT04356833).

\section{Antiplatelet Agents}

\section{Aspirin}

Dysregulated immune response and abnormal coagulation are common occurrences in the pathophysiology of viral sepsis, ARDS, and organ failure in COVID-19. ${ }^{86}$ Platelets play a key role in the pathogenesis of sepsis and thrombosis, and are a potential target for prevention of the complications. ${ }^{87}$

In addition to thrombosis and hemostasis, platelets have immunomodulatory activity, including both inflammatory and anti-inflammatory responses, as well as an effect on antimicrobial host defense. ${ }^{88,89}$ There is evidence that the initial intrinsic defense against infections is mediated by platelet-neutrophil cross-communication that tightly regulates immune and complement responses. ${ }^{88}$ These interactions can facilitate a variety of proinflammatory effects such as cytokine release, endothelial cell activation, platelet-leukocyte interaction, formation of neutrophil extracellular traps, and fibrin/microthrombus formation that while potentially harmful $^{90,91}$ can also inhibit macrophage-dependent inflammation and thus may on balance be protective. ${ }^{87,92,93}$

Acetylsalicylic acid (aspirin) has been extensively studied in ARDS. Aspirin has been associated with ARDS prevention and higher survival rates from acute lung injury in animal models and observational human studies. ${ }^{94-99}$ Aspirin has been associated with reduced mortality in the setting of both prehospital use and use in ICU. ${ }^{97,98}$ These findings, however, were not validated in a phase $2 \mathrm{~b}$ randomized clinical trial. ${ }^{100}$ Some investigators have hypothesized that higher maintenance doses of aspirin $(325-650 \mathrm{mg} / \mathrm{d})$ may be required to 
achieve the desired anti-inflammatory effect in patients with an exuberant immune response. ${ }^{101,102}$

\section{P2Y 12 Receptor Antagonists}

The role of $\mathrm{P}_{2} \mathrm{Y}_{12}$ receptor inhibitors has also been described in ARDS and sepsis. Adenosine diphosphate-mediated activation of the $\mathrm{P}_{2} \mathrm{Y}_{12}$ receptor may occur in many inflammatory and immune cell types including platelets, leukocytes, and dendritic cells. Among 224 consecutive patients admitted for community-acquired pneumonia, those receiving antiplatelet agents (aspirin and/or thienopyridines) for at least 6 months had lower use of the ICU and shorter stay in the hospital compared with age-matched controls. ${ }^{103}$ In a post hoc analysis from the PLATO trial, patients with acute coronary syndromes treated with the potent $\mathrm{P}_{2} \mathrm{Y}_{12}$ inhibitor ticagrelor and aspirin had fewer adverse pulmonary events and sepsis and lower mortality with those events compared with patients treated with the less potent $\mathrm{P}_{2} \mathrm{Y}_{12}$ inhibitor clopidogrel and aspirin. ${ }^{104}$

The XANTHIPPE trial (Examining the Effect of Ticagrelor on Platelet Activation, Platelet-Leukocyte Aggregates, and Acute Lung Injury in Pneumonia) was the first double-blind, placebo-controlled, randomized study to evaluate the effect of ticagrelor on inflammation, platelet activation, and lung function in patients with community- or hospital-acquired pneumonia. ${ }^{105}$ Among 60 randomized patients, ticagrelor administration within 48 hours of pneumonia diagnosis was associated with an anti-inflammatory effect evidenced by reduced platelet-leukocyte aggregates in the circulation, lowered interleukin (IL)-6 levels, and improved lung function with a decrease in supplemental oxygen requirements. However, given the potential bleeding risks, in the absence of phase III trials demonstrating favorable clinical outcomes, these research findings have not translated into routine clinical practice.

With respect to COVID-19 and antiplatelet agents, there are many unknowns as regards their use and utility. First, it is not clear which phase of the disease might best respond. Second, the optimal agent and dose to maximize efficacy while minimizing bleeding risks are unknown. Due to its pleiotropic effects, ticagrelor may have more potent antiinflammatory and even bactericidal characteristics than other agents. ${ }^{106,107}$ Randomized trials evaluating role of aspirin and clopidogrel in COVID-19 patients at increased cardiovascular risk are underway (NCT04333407). Third, antiplatelet therapies may have adverse drug-drug interactions with some investigational COVID-19 therapies such as lopinavir/ritonavir and remdesivir. ${ }^{5,108,109}$ Fourth, thrombocytopenia (immune-mediated or consumption-related) is associated with increased risk for worse clinical outcomes with COVID-19. ${ }^{110,111}$ Finally, the extent to which bleeding risks are increased, particularly in patients with DIC, is unknown.

\section{Dipyridamole}

Dipyridamole is a phosphodiesterase inhibitor that inhibits platelet aggregation by increasing intracellular concentrations of cyclic adenosine monophosphate. ${ }^{112}$ In addition to its well-known antithrombotic properties, dipyridamole may have antiviral effects with proposed activity against influenza in animal models. ${ }^{113}$ In mouse models of viral pneumonia, dipyridamole administration promoted interferon response and prolonged survival in infected mice. Dipyridamole has antiviral effects in vitro, specifically confirming the affinity of dipyridamole for a SARS-CoV-2 main protease $\left(\mathrm{M}^{\text {pro }}\right) .{ }^{114}$ To date, one study has examined dipyridamole in the treatment of COVID-19; 31 patients with COVID-19 were randomized to dipyridamole (150 mg three times a day for 7 days) versus control. In this small study, those treated with dipyridamole showed trends toward higher cure and hospital discharge rates. Increased platelet counts and decreased D-dimer levels were also noted with dipyridamole treatment, attributed to infection resolution. ${ }^{115}$ Further high-quality data are needed to evaluate the anti-SARS-CoV-2 therapeutic potential of dipyridamole.

\section{Vorapaxar}

Vorapaxar is an antiplatelet agent that exerts its antiplatelet activity through antagonism of the protease-activated receptor 1 (PAR-1) and inhibition of thrombin-induced platelet aggregation. ${ }^{116}$ In patients with history of myocardial infarction, or peripheral arterial disease, vorapaxar has been shown to reduce thrombotic cardiovascular events. ${ }^{117}$ The main concern associated with vorapaxar is its increased risk of bleeding events and reports of intracranial hemorrhage in patients with a previous history of stroke. PAR-1 is thought to have an important role in thrombin-induced platelet aggregation, and the link between coagulation, inflammation, and the fibrotic response. As such, investigating vorapaxar in patients with COVID-19 has received some attention. ${ }^{50}$ However, its terminal half-life of 8 days renders it difficult to use in patients with severe COVID-19. To date, there are no registered randomized trials for use of vorapaxar in patients with COVID-19.

\section{Hemostatic Modulating Agents}

\section{Antithrombin}

The single-chain glycosaminoglycan antithrombin, which is produced in the liver, is modestly decreased in patients hospitalized with COVID-19. ${ }^{118,119}$ Thus, reduced antithrombin may be a potential therapeutic target for patients with COVID-19. Furthermore, the $\beta$-isoform of antithrombin binds preferentially to vascular heparin sulfate proteoglycans and initiates prostacyclin production and inhibition of nuclear factor kappa B (NF-kB), resulting in anti-inflammatory effects, which might be further pronounced by the binding of $\beta$-antithrombin to receptors on monocytes. ${ }^{120}$ Limited supporting data exist from patients with severe acute respiratory syndrome (SARS). Compared with healthy individuals such patients had lower levels of the natural inhibitors of coagulation and higher levels of PAI-1.

Blood coagulation parameters were investigated in 94 patients with COVID-19 pneumonia, of whom 49 had "ordinary," 35 had severe, and 10 had critical forms of COVID$19 .{ }^{121}$ When compared with 40 healthy controls, patients in 
all three categories of COVID-19 had significantly lower levels of antithrombin, and the three subsets of patients had similar levels (86.0, 85.6, and 82.4\%). Nebulized antithrombin has resulted in decreased coagulopathy and inflammation in animal models of lung injury. ${ }^{122-124}$ Despite these promising findings, there is to date no clinical evidence to support antithrombin provision to critically ill patients or in those with DIC and COVID-19. In a randomized controlled trial of 2,314 patients with severe sepsis, there was no effect of antithrombin therapy on 28-day mortality. ${ }^{125}$ Moreover, in a meta-analysis of 3,019 patients included in 11 trials, antithrombin administration in critically ill patients was associated with more bleeding events (relative risk [RR]: 1.58; 95\% confidence interval $[\mathrm{CI}] 1.35-1.84) .{ }^{126}$

\section{Thrombomodulin}

Thrombomodulin is an endothelial cell glycoprotein with potent anticoagulant and anti-inflammatory effects mediated through activated protein C (APC)-dependent and APCindependent protein $\mathrm{C}$ mechanisms. In inflammatory states, thrombomodulin production is downregulated and surface thrombomodulin is cleaved so that there is reduced activation of protein $\mathrm{C}^{127}$ The role of recombinant thrombomodulin as a potential modifier of clinical outcomes in patients with sepsis has been evaluated in clinical trials.

The SCARLET study (Sepsis Coagulopathy Asahi Recombinant LE Thrombomodulin) was a randomized placebocontrolled double-blind study of recombinant human soluble thrombomodulin in 800 patients with objective evidence of bacterial infection, sepsis-induced systemic inflammatory response syndrome, and concurrent cardiovascular and/or respiratory dysfunction. ${ }^{128}$ There was no significant between-group differences in the 28-day primary mortality outcome or other secondary endpoints. A post hoc subgroup analysis in patients with coagulopathy reported a trend for reduced mortality compared with placebo (risk difference $-5.40 \%$; $95 \% \mathrm{CI}-1.68 \%$ to $12.48 \%$ ). A subsequent systematic review and meta-analysis suggested lower mortality among patients with (but not in those without) sepsis-induced coagulopathy treated with thrombomodulin (RR: 0.80; 95\% CI, 0.65-0.98). ${ }^{129}$ Currently, there is insufficient evidence to recommend the routine use of thrombomodulin in patients with severe COVID-19. However, investigational use is warranted in selected subgroups with evidence of coagulopathy.

\section{Activated Protein C}

APC can play a key role in reducing the damage caused by wide variety of triggers, including ischemia/reperfusion injury, gastrointestinal inflammation, sepsis, and Ebola virus infection. ${ }^{130}$ In 2002, recombinant human protein C was approved by the U.S. Food and Drug Administration (FDA) for the clinical treatment of severe sepsis and ARDS. Protein C concentrates reduced the risk of mortality in early studies of sepsis and septic shock. However, subsequent clinical trials have reported neutral results. ${ }^{19}$ Specifically, a randomized trial of 1,697 patients did not demonstrate a reduction in mortality at 28 or 90 days after APC was administered in the setting of septic shock, ${ }^{131}$ and subsequent concerns emerged regarding the risk of serious bleeding and death in individuals with bleeding precautions. ${ }^{132} \mathrm{~A}$ possible explanation is that APC may only benefit septic patients complicated by DIC, which was a minority of patients in these trials.

In a study of 27 patients with ARDS (16 treated with recombinant APC and 11 with placebo), the infusion of recombinant APC increased APC levels in the pulmonary compartment and attenuated systemic coagulopathy and pulmonary coagulopathy, providing faster resolution of pulmonary dysfunction without bleeding complications. ${ }^{133}$ However, in a subsequent randomized controlled trial of 71 patients, infusion of recombinant APC for infectious or inflammatory ARDS did not improve alveolocapillary permeability nor the clinical course of ARDS patients. ${ }^{134}$

It is intuitive that protein $C$ concentrates may be more beneficial in patients with significant protein $\mathrm{C}$ reduction. However, in a small study of 11 critically ill COVID-19 patients, protein $\mathrm{C}$ levels were overall increased, with only 4 patients having a protein $C$ level lower than normal. ${ }^{119}$ The protein C mutant, 3K3A-APC, being developed for acute stroke treatment, was engineered to have low anticoagulant activity (so low bleeding risk) while retaining APCs' antiinflammatory and cytoprotective cell signaling properties that may be important in pneumonia. The potential utility of recombinant APC or 3K3A-APC in patients with COVID-19, including those with DIC, is worthy of prospective investigation. ${ }^{135}$

\section{Contact Activation System}

Dysregulation of inflammation and coagulation are hallmarks of COVID-19. The contact activation system, which includes factor XII, factor XI, high-molecular-weight kininogen, and prekallikrein, links inflammation and coagulation by triggering the generation of thrombin and bradykinin. Thrombin promotes clot formation and platelet activation, whereas bradykinin induces the release of proinflammatory cytokines.

In nonhuman primate models of bacterial sepsis, inhibition of factor XIIa or blockade of reciprocal factor XI and factor XII activation reduced the levels of inflammatory cytokines, attenuated microvascular thrombosis, and improved survival. ${ }^{136-139}$ Likewise, in murine models of bacterial sepsis, inflammation and coagulation were attenuated, and survival was enhanced in factor XI-deficient mice compared with their wild-type counterparts. ${ }^{140,141}$ Several inhibitors of factor XII and factor XI are currently under investigation. Studies evaluating the efficacy and safety of these agents in COVID-19 are warranted. ${ }^{142}$

\section{Anti-Inflammatory Agents}

\section{Corticosteroids}

There is conflicting evidence for the use of corticosteroids in COVID-19-related ARDS. ${ }^{143}$ Postulated benefits, including reduction in inflammation and lung injury, must be weighed against the potential risks of delayed viral clearance and increased susceptibility to secondary infections. ${ }^{144-147}$ 
Mechanisms as to whether corticosteroids may modulate thrombotic risk in this patient population are not well-established. As the microvascular and macrovascular thrombotic complications observed in COVID-19 may in part be attributable to the inflammatory environment precipitated by the infection, corticosteroids may reduce thrombotic risk through anti-inflammatory activity. Studies of inflammatory states, particularly rheumatologic conditions, have shown a proportional relationship between inflammatory activity, coagulability, and the risk of VTE. Results regarding frequency of thrombosis with disease-modifying therapies, including corticosteroids, are mixed. ${ }^{148,149}$ Possible beneficial ${ }^{150}$ mechanisms include reductions in levels of procoagulant factors, including fibrinogen and von Willebrand factor. ${ }^{151}$ However, experimental studies have also linked steroid use to increased levels of various clotting factors, and several large-scale studies have shown exogenous glucocorticoids to be a risk factor for thrombosis. ${ }^{150-152}$ Prior studies of corticosteroids in patients with non-COVID-19-related ARDS have shown mixed results with potential benefit limited to only certain subgroups of patients. ${ }^{153}$ Further experience and research, including results from a series of ongoing randomized trials, are needed to better understand the balance of pro- and anticoagulant properties of glucocorticoids in the setting of COVID-19.

\section{Hydroxychloroquine}

Hydroxychloroquine is a 4-aminoquinoline that has an immunomodulatory effect and antithrombotic activity that have been demonstrated in animal models and in patients with systemic lupus erythematosus, rheumatoid arthritis, and antiphospholipid syndrome. ${ }^{154-157}$

In a mouse model, hydroxychloroquine reversed the thrombogenic properties of antiphospholipid antibodies. ${ }^{158}$ Hydroxychloroquine may also have mild antiplatelet effects in patients with antiphospholipid antibodies, and may reduce blood viscosity. ${ }^{154}$ An observational prospective study of patients with antiphospholipid antibody syndrome treated with hydroxychloroquine $200 \mathrm{mg}$ daily demonstrated significant reduction in soluble tissue factor levels at 3 months compared with baseline. ${ }^{159}$ Other potential antithrombotic mechanisms have led to its limited evaluation as a thromboprophylaxis modality in postoperative patients more than three decades ago. ${ }^{160,161}$ However, the exact mechanisms by which it exerts it antithrombotic effect remain largely unknown. Given the known adverse effects with hydroxychloroquine, including QTc prolongation and risk of arrhythmias, ${ }^{162}$ its routine use as an antithrombotic therapy in patients with COVID-19 cannot be recommend until further prospective data emerge.

\section{Statins}

HMG-CoA reductase inhibitors (statins) are widely used as cholesterol-lowering medications in patients with or at increased risk of atherosclerotic cardiovascular disease. ${ }^{163}$ The pleiotropic effects of statins include improving endothelial function, decreasing inflammatory markers, and inhibiting thrombogenicity. ${ }^{164}$ Because patients with COVID-19 may exhibit increased activation of the inflammatory cascade and are prone to venous and arterial thrombosis, leveraging statins as a component of treatment has been proposed. 5,165,166

While no clinical studies have evaluated statin therapy in the management of COVID-19, there is biological plausibility and precedent for such investigation. Through inhibition of the MYD88 stress-response pathway, statins suppress NFkB-induced proinflammatory cytokines. ${ }^{167}$ This may underlie their proposed utility in other viral pneumonias, including those caused by related coronaviruses. ${ }^{168-170}$ Besides mitigating inflammation, antiplatelet and anticoagulant properties can occur via downregulation of tissue factor, upregulation of thrombomodulin, and inhibition of thromboxane $A_{2} \cdot{ }^{171}$ Prior reports have shown that use of statins is associated with reduced rates of VTE, and statins have stabilizing effects on atherosclerotic plaques. ${ }^{172,173}$ At least three clinical trials (NCT04348695, NCT04333407, and NCT04343001) are recruiting COVID-19 patients in randomized statin investigations.

\section{Targeted Immunomodulatory Therapies}

SARS-CoV-2 infection is associated with an inflammatory response marked by increased cytokine levels (e.g., IL-2, IL6, IL-10, tumor necrosis factor- $\alpha$ ). ${ }^{174}$ To treat the inflammatory response generated by severe COVID-19, some have proposed to repurpose immunomodulatory medications approved for other diseases.

One potential target is the complement cascade. A major component of innate immunity, the complement cascade has three independent pathways for activation (classical, lectin, and alternative), each culminating with formation of the lytic membrane attack complex. Eculizumab is an anti-C5 monoclonal antibody that blocks terminal complement activity. One of its clinical applications is complement-mediated thrombotic microangiopathy, namely atypical hemolytic uremic syndrome, which is thought to occur in some patients with COVID-19. ${ }^{20,175}$ In one study of five COVID-19 nonsurvivors, there was evidence of systemic activation of the alternative and lectin-based complement pathways and deposition of the membrane attack complex in both lung and skin. ${ }^{175}$

Based on these data and evidence of efficacy of complement inhibition in murine models of SARS-CoV and MERS$\mathrm{CoV}$, the use of eculizumab in COVID-19 has been proposed. ${ }^{20,175}$ Potential barriers include a 1,000 to 2,000 times increased risk of meningococcal disease (requiring prior vaccination or antibiotic prophylaxis) and cost $(\$ 20,000-$ $\$ 25,000$ per dose).

The Janus kinase (JAK)-signal transducer and activator of transcription pathway is another potential therapeutic target. JAK inhibitors target cytokine signaling pathways and have thus been proposed as a candidate to treat COVID-19. Baricitinib, a JAK1/JAK2 inhibitor approved for the treatment of rheumatoid arthritis, mitigates the systemic inflammatory response and has in vitro activity against SARS-CoV-2 through its numb-associated kinase inhibition that has a high affinity for AAK1, a regulator of clathrin-mediated endocytosis. ${ }^{176}$ Notably, this therapy does carry a FDA warning for an increased incidence of VTE (6/997 patients with baricitinib vs. 0/1,070 controls), ${ }^{177}$ and recent National Institutes of Health (NIH) 
COVID-19 Treatment Guidelines recommends against the use of baricitinib outside of a clinical trial, such as the NIHsponsored ACTT- 2 trial comparing remdesivir \pm baricitinib. ${ }^{178}$ Ruxolitinib is a JAK2 inhibitor approved for patients with myelofibrosis and polycythemia vera. Similar to baricitinib (NCT04340232, NCT04320277, and NCT04346147), ruxolitinib is presently under investigation as a treatment for COVID19 (NCT04334044, NCT04348071, NCT04337359, NCT04331665, NCT04348695, and NCT04338958).

Tocilizumab, an IL-6 receptor antagonist approved for the treatment of rheumatoid arthritis and cytokine release syndrome associated with chimeric antigen receptor-T cell therapy, is included in the Chinese National Health commission guidelines for treating COVID-19. While findings are yet to be published, a randomized trial of 129 hospitalized patients with moderate-to-severe COVID-19 pneumonia suggested that tocilizumab administration may significantly reduce rates of death or life support interventions. ${ }^{179}$ It is thought that tocilizumab may mitigate the proatherothrombotic profile associated with rheumatoid arthritis. However, no specific data related to use of tocilizumab and VTE events in patients with COVID-19 have been published.

\section{Future Directions and Conclusion}

Despite the efforts of the international medical and scientific communities and recent declines in hospitalizations, COVID19 continues to pose an unprecedented challenge. The prognosis for hospitalized patients with COVID-19, especially in the setting of critical illness, continues to be poor. ${ }^{180,181}$ While contributing factors to poor outcomes in patients with COVID-19 are likely multifactorial, thrombotic complications play a major role in the prognosis of these patients. ${ }^{5}$ The development of safe and effective thromboprophylaxis and treatment strategies for thrombotic disease is contingent on an improved understanding of the mechanistic and pathophysiologic basis for such complications in COVID-19 patients. In this document, we have outlined several agents and mechanisms of action for potential for use as antithrombotic agents in the setting of COVID-19. Survey results from group of authors may be helpful for research priority settings for various agents and patient subgroups with COVID-19 (- Table 3). High-quality research investigations into the optimal drug, dose, and duration of therapies to prevent and treat thrombotic complications of COVID-19 offer the potential to improve outcomes of infected patients.

\section{Conflict of Interest}

No specific funding was sought or received for this manuscript. A list of Disclosures for co-authors is available online in the - Supplementary Material (available in the online version).

\section{Acknowledgment}

The authors would like to acknowledge BioRender for providing templates and the platform that were used for creating - Fig. 1.

\section{References}

1 Huang C, Wang Y, Li X, et al. Clinical features of patients infected with 2019 novel coronavirus in Wuhan, China. Lancet 2020;395 (10223):497-506

2 World Health Organization. WHO Director-General's opening remarks at the media briefing on COVID-19 - 11 March 2020. Available at: https://www.who.int/dg/speeches/detail/who-director-general-s-opening-remarks-at-the-media-briefing-oncovid-19-11-march-2020. Accessed March 12, 2020

3 Driggin E, Madhavan MV, Bikdeli B, et al. Cardiovascular considerations for patients, health care workers, and health systems during the coronavirus disease 2019 (COVID-19) pandemic. J Am Coll Cardiol 2020;75(18)2352-2371

4 Clerkin KJ, Fried JA, Raikhelkar J, et al. COVID-19 and cardiovascular disease. Circulation 2020;141(20):1648-1655

5 Bikdeli B, Madhavan MV, Jimenez D, et al. COVID-19 and thrombotic or thromboembolic disease: implications for prevention, antithrombotic therapy, and follow-up. J Am Coll Cardiol 2020. Doi: 10.1016/j.jacc.2020.04.031

6 Cui S, Chen S, Li X, Liu S, Wang F. Prevalence of venous thromboembolism in patients with severe novel coronavirus pneumonia. J Thromb Haemost 2020

7 Klok FA, Kruip M, van der Meer NJM, et al. Incidence of thrombotic complications in critically ill ICU patients with COVID-19. Thromb Res 2020. Doi: 10.1016/j.thromres.2020.04.041

8 Helms J, Tacquard C, Severac F, et al; CRICS TRIGGERSEP Group (Clinical Research in Intensive Care and Sepsis Trial Group for Global Evaluation and Research in Sepsis). High risk of thrombosis in patients with severe SARS-CoV-2 infection: a multicenter prospective cohort study. Intensive Care Med 2020:1-10. Doi: 10.1007/s00134-020-06062-x

9 Oxley TJ, Mocco J, Majidi S, et al. Large-vessel stroke as a presenting feature of Covid-19 in the young. $\mathrm{N}$ Engl J Med 2020;382(20):e60

10 Bangalore S, Sharma A, Slotwiner A, et al. ST-segment elevation in patients with Covid-19 - a case series. N Engl J Med 2020. Doi: 10.1056/NEJMc2009020

11 Bellosta R, Luzzani L, Natalini G, et al. Acute limb ischemia in patients with COVID-19 pneumonia. J Vasc Surg 2020. Doi: 10.1016/j.jvs.2020.04.483

12 Akima S, McLintock C, Hunt BJRE. RE: ISTH interim guidance to recognition and management of coagulopathy in COVID-19. J Thromb Haemost 2020. Doi: 10.1111/jth.14853

13 Barrett CD, Moore HB, Yaffe MB, Moore EE. ISTH interim guidance on recognition and management of coagulopathy in COVID19: a comment. J Thromb Haemost 2020. Doi: 10.1111/jth.14860

14 Thachil J, Tang N, Gando S, et al. ISTH interim guidance on recognition and management of coagulopathy in COVID-19. J Thromb Haemost 2020;18(5):1023-1026

15 Zhai Z, Li C, Chen Y, et al; Prevention Treatment of VTE Associated with COVID-19 Infection Consensus Statement Group. Prevention and treatment of venous thromboembolism associated with coronavirus disease 2019 infection: a consensus statement before guidelines. Thromb Haemost 2020. Doi: 10.1055/s0040-1710019

16 Vivas D, Roldan V, Esteve-Pastor MA, et al. Recommendations on antithrombotic treatment during the COVID-19 pandemic. Position statement of the Working Group on Cardiovascular Thrombosis of the Spanish Society of Cardiology. Rev Esp Cardiol 2020. Doi: 10.1016/j.recesp.2020.04.006

17 Marietta M, Ageno W, Artoni A, et al. COVID-19 and haemostasis: a position paper from Italian Society on Thrombosis and Haemostasis (SISET). Blood Transfus 2020. Doi: 10.2450/2020.0083-20

18 Casini A, Alberio L, Angelillo-Scherrer A, et al. Thromboprophylaxis and laboratory monitoring for in-hospital patients with COVID-19 - a Swiss consensus statement by the Working Party Hemostasis. Swiss Med Wkly 2020;150:w20247 
19 Murao S, Yamakawa K. A systematic summary of systematic reviews on anticoagulant therapy in sepsis. J Clin Med 2019;8 (11):E1869

20 Campbell CM, Kahwash R. Will complement inhibition be the new target in treating COVID-19 related systemic thrombosis? Circulation 2020. Doi: 10.1161/CIRCULATIONAHA.120.047419

21 Thachil J. The versatile heparin in COVID-19. J Thromb Haemost 2020;18(05):1020-1022

22 Garcia DA, Baglin TP, Weitz JI, Samama MM. Parenteral anticoagulants: antithrombotic therapy and prevention of thrombosis, 9th ed: American College of Chest Physicians EvidenceBased Clinical Practice Guidelines. Chest 2012;141(02): e24S-e43S

23 Poterucha TJ, Libby P, Goldhaber SZ. More than an anticoagulant: do heparins have direct anti-inflammatory effects? Thromb Haemost 2017;117(03):437-444

24 Belen-Apak FB, Sarialioglu F. The old but new: can unfractioned heparin and low molecular weight heparins inhibit proteolytic activation and cellular internalization of SARS-CoV2 by inhibition of host cell proteases? Med Hypotheses 2020;142:109743

25 Liu J, Li J, Arnold K, et al. Using heparin molecules to manage COVID-2019. Res Pract Thromb Haemost 2020. Doi: 10.1002/ rth2.12353

26 Obi AT, Tignanelli CJ, Jacobs BN, et al. Empirical systemic anticoagulation is associated with decreased venous thromboembolism in critically ill influenza A H1N1 acute respiratory distress syndrome patients. J Vasc Surg Venous Lymphat Disord 2019;7 (03):317-324

27 Obi AT, Barnes GD, Wakefield TW, et al. Practical diagnosis and treatment of suspected venous thromboembolism during COVID-19 pandemic. J Vasc Surg Venous Lymphat Disord 2020:S2213-333X(20)30221-3

28 Cohoon KP, Mahé G, Tafur AJ, et al. Emergence of institutional antithrombotic protocols for coronavirus. Res Pract Thromb Haemost 2019. Doi: 10.1002/rth2.12358

29 Eikelboom JW, Hirsh J. Monitoring unfractionated heparin with the aPTT: time for a fresh look. Thromb Haemost 2006;96(05): 547-552

30 Bowles L, Platton S, Yartey N, et al. Lupus anticoagulant and abnormal coagulation tests in patients with Covid-19. N Engl J Med 2020. Doi: 10.1056/NEJMc2013656

31 Vandiver JW, Vondracek TG. Antifactor Xa levels versus activated partial thromboplastin time for monitoring unfractionated heparin. Pharmacotherapy 2012;32(06):546-558

32 Mycroft-West C, Su D, Elli S, et al. The 2019 coronavirus (SARSCoV-2) surface protein (Spike) S1 Receptor Binding Domain undergoes conformational change upon heparin binding. bioRxiv 2020: 2020.02.29.971093

33 Hoffmann M, Kleine-Weber H, Schroeder S, et al. SARS-CoV-2 cell entry depends on ACE2 and TMPRSS2 and is blocked by a clinically proven protease inhibitor. Cell 2020;181(02): 271-280

34 Shang J, Ye G, Shi K, et al. Structural basis of receptor recognition by SARS-CoV-2. Nature 2020;581(7807):221-224

35 Lang J, Yang N, Deng J, et al. Inhibition of SARS pseudovirus cell entry by lactoferrin binding to heparan sulfate proteoglycans. PLoS One 2011;6(08):e23710

36 Dou H, Song A, Jia S, Zhang L. Heparinoids danaparoid and sulodexide as clinically used drugs. Prog Mol Biol Transl Sci 2019;163:55-74

37 Frantzeskaki F, Armaganidis A, Orfanos SE. Immunothrombosis in acute respiratory distress syndrome: cross talks between inflammation and coagulation. Respiration 2017;93(03): 212-225

38 Warkentin TE. Heparin-induced thrombocytopenia in critically ill patients. Semin Thromb Hemost 2015;41(01):49-60

39 Decousus H, Tapson VF, Bergmann JF, et al; IMPROVE Investigators. Factors at admission associated with bleeding risk in medical patients: findings from the IMPROVE investigators. Chest 2011;139(01):69-79

40 Burgess JK, Chong BH. The platelet proaggregating and potentiating effects of unfractionated heparin, low molecular weight heparin and heparinoid in intensive care patients and healthy controls. Eur J Haematol 1997;58(04):279-285

41 Minakata D, Fujiwara SI, Hayakawa J, et al. Comparison of danaparoid sodium and synthetic protease inhibitors for the treatment of disseminated intravascular coagulation associated with hematological malignancies: a retrospective analysis. Acta Haematol 2019:1-10

42 Marongiu F, Grandone E, Barcellona D. Pulmonary thrombosis in 2019-nCoV pneumonia? J Thromb Haemost 2020. Doi: 10.1111/ jth.14818

43 Wichmann D, Sperhake JP, Lütgehetmann M, et al. Autopsy findings and venous thromboembolism in patients with COVID-19: a prospective cohort study. Ann Intern Med 2020. Doi: 10.7326/M20-2003

44 Hagiwara S, Iwasaka H, Hidaka S, Hishiyama S, Noguchi T. Danaparoid sodium inhibits systemic inflammation and prevents endotoxin-induced acute lung injury in rats. Crit Care 2008;12(02):R43

45 Iba T, Miyasho T. Danaparoid sodium attenuates the increase in inflammatory cytokines and preserves organ function in endotoxemic rats. Crit Care 2008;12(04):R86

46 Juschten J, Tuinman PR, Juffermans NP, Dixon B, Levi M, Schultz MJ. Nebulized anticoagulants in lung injury in critically ill patients-an updated systematic review of preclinical and clinical studies. Ann Transl Med 2017;5(22):444

47 Bikdeli B, McAndrew T, Crowley A, et al. Individual patient data pooled analysis of randomized trials of bivalirudin versus heparin in acute myocardial infarction: rationale and methodology. Thromb Haemost 2020;120(02):348-362

48 Salter BS, Weiner MM, Trinh MA, et al. Heparin-induced thrombocytopenia: a comprehensive clinical review. J Am Coll Cardiol 2016;67(21):2519-2532

49 Schein JR, White CM, Nelson WW, Kluger J, Mearns ES, Coleman CI. Vitamin K antagonist use: evidence of the difficulty of achieving and maintaining target INR range and subsequent consequences. Thromb J 2016;14:14

50 Jose RJ, Manuel A. COVID-19 cytokine storm: the interplay between inflammation and coagulation. Lancet Respir Med 2020:S2213-2600(20)30216-2

51 Mega JL, Braunwald E, Wiviott SD, et al; ATLAS ACS 2-TIMI 51 Investigators. Rivaroxaban in patients with a recent acute coronary syndrome. N Engl J Med 2012;366(01):9-19

52 Eikelboom JW, Connolly SJ, Bosch J, et al; COMPASS Investigators. Rivaroxaban with or without aspirin in stable cardiovascular disease. N Engl J Med 2017;377(14):1319-1330

53 Bonaca MP, Bauersachs RM, Anand SS, et al. Rivaroxaban in peripheral artery disease after revascularization. $\mathrm{N}$ Engl J Med 2020;382(21):1994-2004

54 Cohen AT, Spiro TE, Büller HR, et al; MAGELLAN Investigators. Rivaroxaban for thromboprophylaxis in acutely ill medical patients. N Engl J Med 2013;368(06):513-523

55 Spyropoulos AC, Ageno W, Albers GW, et al; MARINER Investigators. Rivaroxaban for thromboprophylaxis after hospitalization for medical illness. N Engl J Med 2018;379(12):1118-1127

56 Cohen AT, Harrington RA, Goldhaber SZ, et al; APEX Investigators. Extended thromboprophylaxis with betrixaban in acutely ill medical patients. N Engl J Med 2016;375(06):534-544

57 Goldhaber SZ, Leizorovicz A, Kakkar AK, et al; ADOPT Trial Investigators. Apixaban versus enoxaparin for thromboprophylaxis in medically ill patients. N Engl J Med 2011;365(23): 2167-2177

58 Spyropoulos AC, Lipardi C, Xu J, et al. Improved benefit risk profile of rivaroxaban in a subpopulation of the MAGELLAN study. Clin Appl Thromb Hemost 2019;25:1076029619886022 
59 Yang X, Yu Y, Xu J, et al. Clinical course and outcomes of critically ill patients with SARS-CoV-2 pneumonia in Wuhan, China: a single-centered, retrospective, observational study. Lancet Respir Med 2020;8(05):475-481

60 Bhatraju PK, Ghassemieh BJ, Nichols M, et al. Covid-19 in critically ill patients in the Seattle region - case series. N Engl J Med 2020;382:2012-2022

61 Testa S, Prandoni P, Paoletti O, et al. Direct oral anticoagulant plasma levels' striking increase in severe COVID-19 respiratory syndrome patients treated with antiviral agents: the Cremona experience. J Thromb Haemost 2020. Doi: 10.1111/jth.14871

62 Kearon C, Akl EA, Ornelas J, et al. Antithrombotic therapy for VTE Disease: CHEST guideline and expert panel report. Chest 2016; 149(02):315-352

$63 \mathrm{Wu} \mathrm{B}$, Lu J, Yang M, Xu T. Sulodexide for treating venous leg ulcers. Cochrane Database Syst Rev 2016;(06):CD010694

64 Lasierra-Cirujeda J, Coronel P, Aza M, Gimeno M. Use of sulodexide in patients with peripheral vascular disease. J Blood Med 2010;1:105-115

65 Lauver DA, Lucchesi BR. Sulodexide: a renewed interest in this glycosaminoglycan. Cardiovasc Drug Rev 2006;24(3-4):214-226

66 Mauro M, Palmieri GC, Palazzini E, Barbanti M, Calanni Rindina F, Milani MR. Pharmacodynamic effects of single and repeated doses of oral sulodexide in healthy volunteers. A placebo-controlled study with an enteric-coated formulation. Curr Med Res Opin 1993;13(02):87-95

67 Femiano F, Gombos F, Scully C. Recurrent aphthous stomatitis unresponsive to topical corticosteroids: a study of the comparative therapeutic effects of systemic prednisone and systemic sulodexide. Int J Dermatol 2003;42(05):394-397

68 Bilinska M, Wolszakiewicz J, Duda M, Janas J, Beresewicz A, Piotrowicz R. Antioxidative activity of sulodexide, a glycosaminoglycan, in patients with stable coronary artery disease: a pilot study. Med Sci Monit 2009;15(12):CR618-CR623

69 Bikdeli B, Chatterjee S, Kirtane AJ, et al. Sulodexide versus control and the risk of thrombotic and hemorrhagic events: metaanalysis of randomized trials. Semin Thromb Hemost 2020 (in press)

70 Doctor gambles on clot-busting drug to save virus patients. Available at: https://apnews.com/5c0dc863f214d32a53c6280c31 cf3f56. Accessed April 20, 2020

71 Wang J, Hajizadeh N, Moore EE, et al. Tissue plasminogen activator (tPA) treatment for COVID-19 associated acute respiratory distress syndrome (ARDS): a case series. J Thromb Haemost 2020. Doi: $10.1111 /$ jth.14828

72 Barrett CD, Morre HB, Moore EE, et al. Fibrinolytic therapy for refractory COVID 19 acute respiratory distress syndrome: scientific rationale and review. Research and practice in Thrombosis and Haemostasis 2020. Available at: https://doi.org/10.1002/ rth2.12357. Accessed May 21, 2020

73 Xu Z, Shi L, Wang Y, et al. Pathological findings of COVID-19 associated with acute respiratory distress syndrome. Lancet Respir Med 2020;8(04):420-422

74 Zhou F, Yu T, Du R, et al. Clinical course and risk factors for mortality of adult inpatients with COVID-19 in Wuhan, China: a retrospective cohort study. Lancet 2020;395(10229):1054-1062

75 Moore HB, Barrett CD, Moore EE, et al. Is there a role for tissue plasminogen activator (tPA) as a novel treatment for refractory COVID-19 associated acute respiratory distress syndrome (ARDS)? J Trauma Acute Care Surg 2020. Doi: 10.1097/ TA.0000000000002694

76 Hardaway RM, Williams $\mathrm{CH}$, Marvasti M, et al. Prevention of adult respiratory distress syndrome with plasminogen activator in pigs. Crit Care Med 1990;18(12):1413-1418

77 Stringer KA, Hybertson BM, Cho OJ, Cohen Z, Repine JE. Tissue plasminogen activator (tPA) inhibits interleukin- 1 induced acute lung leak. Free Radic Biol Med 1998;25(02):184-188
78 Liu C, Ma Y, Su Z, et al. Meta-analysis of preclinical studies of fibrinolytic therapy for acute lung injury. Front Immunol 2018; 9:1898

79 Hardaway RM, Harke $\mathrm{H}$, Tyroch $\mathrm{AH}$, Williams $\mathrm{CH}$, Vazquez Y, Krause GF. Treatment of severe acute respiratory distress syndrome: a final report on a phase I study. Am Surg 2001;67(04): 377-382

80 Abdelaal Ahmed Mahmoud A, Mahmoud HE, Mahran MA, Khaled M. Streptokinase versus unfractionated heparin nebulization in patients with severe acute respiratory distress syndrome (ARDS): a randomized controlled trial with observational controls. J Cardiothorac Vasc Anesth 2020;34(02):436-443

81 Brass LM, Lichtman JH, Wang Y, Gurwitz JH, Radford MJ, Krumholz HM. Intracranial hemorrhage associated with thrombolytic therapy for elderly patients with acute myocardial infarction: results from the Cooperative Cardiovascular Project. Stroke 2000;31(08):1802-1811

82 Wahlgren N, Ahmed N, Dávalos A, et al; SITS-MOST investigators. Thrombolysis with alteplase for acute ischaemic stroke in the Safe Implementation of Thrombolysis in Stroke-Monitoring Study (SITS-MOST): an observational study. Lancet 2007;369 (9558):275-282

83 Chatterjee S, Weinberg I, Yeh RW, et al. Risk factors for intracranial haemorrhage in patients with pulmonary embolism treated with thrombolytic therapy development of the PE-CH score. Thromb Haemost 2017;117(02):246-251. Doi: 10.1111/jth.14872

84 Huang X, Moreton FC, Kalladka D, et al. Coagulation and fibrinolytic activity of tenecteplase and alteplase in acute ischemic stroke. Stroke 2015;46(12):3543-3546

85 Whyte CS, Morrow GB, Mitchell JL, Chowdary P, Mutch NJ. Fibrinolytic abnormalities in acute respiratory distress syndrome (ARDS) and versatility of thrombolytic drugs to treat COVID-19. J Thromb Haemost 2020

86 Li H, Liu L, Zhang D, et al. SARS-CoV-2 and viral sepsis: observations and hypotheses. Lancet 2020;395(10235):1517-1520

87 de Stoppelaar SF, van 't Veer C, van der Poll T. The role of platelets in sepsis. Thromb Haemost 2014;112(04):666-677

88 Koupenova M, Corkrey HA, Vitseva O, et al. The role of platelets in mediating a response to human influenza infection. Nat Commun 2019;10(01):1780

89 de Stoppelaar SF, van 't Veer C, Claushuis TA, Albersen BJ, Roelofs JJ, van der Poll T. Thrombocytopenia impairs host defense in gram-negative pneumonia-derived sepsis in mice. Blood 2014; 124(25):3781-3790

90 Semple JW, Italiano JE Jr, Freedman J. Platelets and the immune continuum. Nat Rev Immunol 2011;11(04):264-274

91 Yeaman MR. Platelets in defense against bacterial pathogens. Cell Mol Life Sci 2010;67(04):525-544

92 Xiang B, Zhang G, Guo L, et al. Platelets protect from septic shock by inhibiting macrophage-dependent inflammation via the cyclooxygenase 1 signalling pathway. Nat Commun 2013;4(01):2657

93 Gudbrandsdottir S, Hasselbalch $\mathrm{HC}$, Nielsen $\mathrm{CH}$. Activated platelets enhance IL-10 secretion and reduce TNF- $\alpha$ secretion by monocytes. J Immunol 2013;191(08):4059-4067

94 Zarbock A, Singbartl K, Ley K. Complete reversal of acid-induced acute lung injury by blocking of platelet-neutrophil aggregation. J Clin Invest 2006;116(12):3211-3219

95 Looney MR, Nguyen JX, Hu Y, Van Ziffle JA, Lowell CA, Matthay MA. Platelet depletion and aspirin treatment protect mice in a two-event model of transfusion-related acute lung injury. J Clin Invest 2009;119(11):3450-3461

96 Wang L, Li H, Gu X, Wang Z, Liu S, Chen L. Effect of antiplatelet therapy on acute respiratory distress syndrome and mortality in critically ill patients: a meta-analysis. PLoS One 2016;11(05): e0154754

97 Boyle AJ, Di Gangi S, Hamid UI, et al. Aspirin therapy in patients with acute respiratory distress syndrome (ARDS) is associated 
with reduced intensive care unit mortality: a prospective analysis. Crit Care 2015;19(01):109

98 Chen W, Janz DR, Bastarache JA, et al. Prehospital aspirin use is associated with reduced risk of acute respiratory distress syndrome in critically ill patients: a propensity-adjusted analysis. Crit Care Med 2015;43(04):801-807

99 Panka BA, de Grooth HJ, Spoelstra-de Man AM, Looney MR, Tuinman PR. Prevention or treatment of ARDS with aspirin: a review of preclinical models and meta-analysis of clinical studies. Shock 2017;47(01):13-21

100 Kor DJ, Carter RE, Park PK, et al; US Critical Illness and Injury Trials Group: Lung Injury Prevention with Aspirin Study Group (USCIITG: LIPS-A). Effect of aspirin on development of ARDS in atrisk patients presenting to the emergency department: the LIPSA randomized clinical trial. JAMA 2016;315(22):2406-2414

101 Kuschner RA. Aspirin and acute respiratory distress syndrome. JAMA 2016;316(12):1317-1318

102 Mezidi M, Guérin C. Aspirin for prevention of acute respiratory distress syndrome (ARDS): let's not throw the baby with the water!. Ann Transl Med 2016;4(19):376

103 Gross AK, Dunn SP, Feola DJ, et al. Clopidogrel treatment and the incidence and severity of community acquired pneumonia in a cohort study and meta-analysis of antiplatelet therapy in pneumonia and critical illness. J Thromb Thrombolysis 2013;35(02): 147-154

104 Storey RF, James SK, Siegbahn A, et al. Lower mortality following pulmonary adverse events and sepsis with ticagrelor compared to clopidogrel in the PLATO study. Platelets 2014;25(07): 517-525

105 Sexton TR, Zhang G, Macaulay TE, et al. Ticagrelor reduces thromboinflammatory markers in patients with pneumonia. JACC Basic Transl Sci 2018;3(04):435-449

106 Aungraheeta R, Conibear A, Butler M, et al. Inverse agonism at the P2Y12 receptor and ENT1 transporter blockade contribute to platelet inhibition by ticagrelor. Blood 2016;128(23):2717-2728

107 Lancellotti P, Musumeci L, Jacques N, et al. Antibacterial activity of ticagrelor in conventional antiplatelet dosages against antibiotic-resistant Gram-positive bacteria. JAMA Cardiol 2019;4(06): 596-599

108 Itkonen MK, Tornio A, Lapatto-Reiniluoto O, et al. Clopidogrel increases dasabuvir exposure with or without ritonavir, and ritonavir inhibits the bioactivation of clopidogrel. Clin Pharmacol Ther 2019;105(01):219-228

109 Marsousi N, Daali Y, Fontana P, et al. Impact of boosted antiretroviral therapy on the pharmacokinetics and efficacy of clopidogrel and prasugrel active metabolites. Clin Pharmacokinet 2018;57(10):1347-1354

110 Terpos E, Ntanasis-Stathopoulos I, Elalamy I, et al. Hematological findings and complications of COVID-19. Am J Hematol 2020

111 Lippi G, Plebani M, Henry BM. Thrombocytopenia is associated with severe coronavirus disease 2019 (COVID-19) infections: a meta-analysis. Clin Chim Acta 2020;506:145-148

112 Gresele P, Momi S, Falcinelli E. Anti-platelet therapy: phosphodiesterase inhibitors. Br J Clin Pharmacol 2011;72(04):634-646

113 Tonew E, Indulen MK, Dzeguze DR. Antiviral action of dipyridamole and its derivatives against influenza virus A. Acta Virol 1982;26(03):125-129

114 Li Z, Li X, Huang Y-Y, et al. FEP-based screening prompts drug repositioning against COVID-19. bioRxiv 2020: 2020.03.23. 004580

115 Liu X, Li Z, Liu S, et al. Potential therapeutic effects of dipyridamole in the severely ill patients with COVID-19. Acta Pharm Sin B 2020. Doi: $10.1016 /$ j.apsb.2020.04.008

116 Baker NC, Lipinski MJ, Lhermusier T, Waksman R. Overview of the 2014 Food and Drug Administration Cardiovascular and Renal Drugs Advisory Committee meeting about vorapaxar. Circulation 2014;130(15):1287-1294
117 Morrow DA, Braunwald E, Bonaca MP, et al; TRA 2P-TIMI 50 Steering Committee and Investigators. Vorapaxar in the secondary prevention of atherothrombotic events. N Engl J Med 2012;366(15):1404-1413

118 Tang N, Li D, Wang X, Sun Z. Abnormal coagulation parameters are associated with poor prognosis in patients with novel coronavirus pneumonia. J Thromb Haemost 2020;18(04): 844-847

119 Panigada M, Bottino N, Tagliabue P, et al. Hypercoagulability of COVID-19 patients in intensive care unit. A report of thromboelastography findings and other parameters of hemostasis. J Thromb Haemost 2020. Doi: 10.1111/jth.14850

120 Rezaie AR, Giri H. Antithrombin: an anticoagulant, anti-inflammatory and antibacterial serpin. J Thromb Haemost 2020;18 (03):528-533

121 Han H, Yang L, Liu R, et al. Prominent changes in blood coagulation of patients with SARS-CoV-2 infection. Clin Chem Lab Med 2020 /j/cclm.ahead-of-print/cclm-2020-0188/cclm-2020-0188. xml . Doi: 10.1515/cclm-2020-0188

122 Hofstra JJ, Vlaar AP, Cornet AD, et al. Nebulized anticoagulants limit pulmonary coagulopathy, but not inflammation, in a model of experimental lung injury. J Aerosol Med Pulm Drug Deliv 2010;23(02):105-111

123 Cornet AD, Hofstra JJ, Vlaar AP, et al. Nebulized anticoagulants limit coagulopathy but not inflammation in pseudomonas aeruginosa-induced pneumonia in rats. Shock 2011;36(04): 417-423

124 Uchiba M, Okajima K, Murakami K. Effects of various doses of antithrombin III on endotoxin-induced endothelial cell injury and coagulation abnormalities in rats. Thromb Res 1998;89(05): 233-241

125 Warren BL, Eid A, Singer P, et al; KyberSept Trial Study Group. Caring for the critically ill patient. High-dose antithrombin III in severe sepsis: a randomized controlled trial. JAMA 2001;286 (15):1869-1878

126 Allingstrup M, Wetterslev J, Ravn FB, Møller AM, Afshari A. Antithrombin III for critically ill patients: a systematic review with meta-analysis and trial sequential analysis. Intensive Care Med 2016;42(04):505-520

127 Ito T, Thachil J, Asakura H, Levy JH, Iba T. Thrombomodulin in disseminated intravascular coagulation and other critical conditions-a multi-faceted anticoagulant protein with therapeutic potential. Crit Care 2019;23(01):280

128 Vincent JL, Francois B, Zabolotskikh I, et al; SCARLET Trial Group. Effect of a recombinant human soluble thrombomodulin on mortality in patients with sepsis-associated coagulopathy: the SCARLET randomized clinical trial. JAMA 2019;321(20): 1993-2002

129 Valeriani E, Squizzato A, Gallo A, et al. Efficacy and safety of recombinant human soluble thrombomodulin in patients with sepsis-associated coagulopathy: a systematic review and metaanalysis. J Thromb Haemost 2020. Doi: 10.1111/jth.14812

130 Griffin JH, Zlokovic BV, Mosnier LO. Activated protein C: biased for translation. Blood 2015;125(19):2898-2907

131 Ranieri VM, Thompson BT, Barie PS, et al; PROWESS-SHOCK Study Group. Drotrecogin alfa (activated) in adults with septic shock. N Engl J Med 2012;366(22):2055-2064

132 Gentry CA, Gross KB, Sud B, Drevets DA. Adverse outcomes associated with the use of drotrecogin alfa (activated) in patients with severe sepsis and baseline bleeding precautions. Crit Care Med 2009;37(01):19-25

133 Cornet AD, Hofstra JJ, Vlaar AP, et al. Activated protein C attenuates pulmonary coagulopathy in patients with acute respiratory distress syndrome. J Thromb Haemost 2013;11 (05):894-901

134 Cornet AD, Groeneveld AB, Hofstra JJ, et al. Recombinant human activated protein $C$ in the treatment of acute respiratory distress 
syndrome: a randomized clinical trial. PLoS One 2014;9(03): e90983

135 Al-Abdallat MM, Payne DC, Alqasrawi S, et al; Jordan MERS-CoV Investigation Team. Hospital-associated outbreak of Middle East respiratory syndrome coronavirus: a serologic, epidemiologic, and clinical description. Clin Infect Dis 2014;59(09):1225-1233

136 Lupu F, Keshari R, Silasi R, et al. Blocking activated factor XII with a monoclonal antibody prevents organ failure and saves baboons challenged with heat-inactivated S. aureus. Res Pr Thromb Haemost 2019;3(Suppl 1):127-128

137 Silasi R, Keshari RS, Lupu C, et al. Inhibition of contact-mediated activation of factor XI protects baboons against $S$ aureus-induced organ damage and death. Blood Adv 2019;3(04):658-669

138 Jansen PM, Pixley RA, Brouwer M, et al. Inhibition of factor XII in septic baboons attenuates the activation of complement and fibrinolytic systems and reduces the release of interleukin- 6 and neutrophil elastase. Blood 1996;87(06):2337-2344

139 Pixley RA, De La Cadena R, Page JD, et al. The contact system contributes to hypotension but not disseminated intravascular coagulation in lethal bacteremia. In vivo use of a monoclonal anti-factor XII antibody to block contact activation in baboons. J Clin Invest 1993;91(01):61-68

140 Tucker EI, Verbout NG, Leung PY, et al. Inhibition of factor XI activation attenuates inflammation and coagulopathy while improving the survival of mouse polymicrobial sepsis. Blood 2012;119(20):4762-4768

141 Luo D, Szaba FM, Kummer LW, et al. Factor XI-deficient mice display reduced inflammation, coagulopathy, and bacterial growth during listeriosis. Infect Immun 2012;80(01):91-99

142 Shatzel JJ, DeLoughery EP, Lorentz CU, et al. The contact activation system as a potential therapeutic target in patients with COVID-19. Res Pract Thromb Haemost 2020. Doi: 10.1002/ rth2.12349

143 Sanders JM, Monogue ML, Jodlowski TZ, Cutrell JB. Pharmacologic treatments for coronavirus disease 2019 (COVID-19): a review. JAMA 2020. Doi: 10.1001/jama.2020.6019

144 Wu C, Chen X, Cai Y, et al. Risk factors associated with acute respiratory distress syndrome and death in patients with coronavirus disease 2019 pneumonia in Wuhan, China. JAMA Intern Med 2020:e200994

145 Stockman LJ, Bellamy R, Garner P. SARS: systematic review of treatment effects. PLoS Med 2006;3(09):e343

146 Arabi YM, Mandourah Y, Al-Hameed F, et al; Saudi Critical Care Trial Group. Corticosteroid therapy for critically ill patients with middle east respiratory syndrome. Am J Respir Crit Care Med 2018;197(06):757-767

147 Lansbury L, Rodrigo C, Leonardi-Bee J, Nguyen-Van-Tam J, Lim WS. Corticosteroids as adjunctive therapy in the treatment of influenza. Cochrane Database Syst Rev 2019;2:CD010406

148 Lee JJ, Pope JE. A meta-analysis of the risk of venous thromboembolism in inflammatory rheumatic diseases. Arthritis Res Ther 2014;16(05):435

149 Zöller B, Li X, Sundquist J, Sundquist K. Risk of pulmonary embolism in patients with autoimmune disorders: a nationwide follow-up study from Sweden. Lancet 2012;379(9812):244-249

150 Johannesdottir SA, Horváth-Puhó E, Dekkers OM, et al. Use of glucocorticoids and risk of venous thromboembolism: a nationwide population-based case-control study. JAMA Intern Med 2013;173(09):743-752

151 van Zaane B, Nur E, Squizzato A, et al. Systematic review on the effect of glucocorticoid use on procoagulant, anti-coagulant and fibrinolytic factors. J Thromb Haemost 2010;8(11):2483-2493

152 Huerta C, Johansson S, Wallander MA, García Rodríguez LA. Risk factors and short-term mortality of venous thromboembolism diagnosed in the primary care setting in the United Kingdom. Arch Intern Med 2007;167(09):935-943
153 Khilnani GC, Hadda V. Corticosteroids and ARDS: a review of treatment and prevention evidence. Lung India 2011;28(02): 114-119

154 Espinola RG, Pierangeli SS, Gharavi AE, Harris EN. Hydroxychloroquine reverses platelet activation induced by human IgG antiphospholipid antibodies. Thromb Haemost 2002;87(03): 518-522

155 Petri M. Use of hydroxychloroquine to prevent thrombosis in systemic lupus erythematosus and in antiphospholipid antibody-positive patients. Curr Rheumatol Rep 2011;13(01):77-80

156 Schreiber K, Sciascia S, de Groot PG, et al. Antiphospholipid syndrome. Nat Rev Dis Primers 2018;4:18005

157 Ruiz-Irastorza G, Ramos-Casals M, Brito-Zeron P, Khamashta MA. Clinical efficacy and side effects of antimalarials in systemic lupus erythematosus: a systematic review. Ann Rheum Dis 2010;69(01):20-28

158 Edwards MH, Pierangeli S, Liu X, Barker JH, Anderson G, Harris EN. Hydroxychloroquine reverses thrombogenic properties of antiphospholipid antibodies in mice. Circulation 1997;96(12): 4380-4384

159 Schreiber K, Breen K, Parmar K, Rand JH, Wu XX, Hunt BJ. The effect of hydroxychloroquine on haemostasis, complement, inflammation and angiogenesis in patients with antiphospholipid antibodies. Rheumatology (Oxford) 2018;57(01): 120-124

160 Johansson E, Forsberg K, Johnsson H. Clinical and experimental evaluation of the thromboprophylactic effect of hydroxychloroquine sulfate after total hip replacement. Haemostasis 1981;10 (02):89-96

161 Loudon JR. Hydroxychloroquine and postoperative thromboembolism after total hip replacement. Am J Med 1988;85 (4A):57-61

162 Bessière $\mathrm{F}$, Roccia $\mathrm{H}$, Delinière $\mathrm{A}$, et al. Assessment of QT intervals in a case series of patients with coronavirus disease 2019 (COVID-19) infection treated with hydroxychloroquine alone or in combination with azithromycin in an intensive care unit. JAMA Cardiol 2020:e201787

163 Grundy SM, Stone NJ, Bailey AL, et al. 2018 AHA/ACC/AACVPR/ AAPA/ABC/ACPM/ADA/AGS/APhA/ASPC/NLA/PCNA guideline on the management of blood cholesterol: executive summary: a report of the American College of Cardiology/American Heart Association Task Force on Clinical Practice Guidelines. J Am Coll Cardiol 2019;73(24):3168-3209

164 Oesterle A, Laufs U, Liao JK. Pleiotropic effects of statins on the cardiovascular system. Circ Res 2017;120(01):229-243

165 Mehta P, McAuley DF, Brown M, Sanchez E, Tattersall RS, Manson JJ; HLH Across Speciality Collaboration, UK. COVID-19: consider cytokine storm syndromes and immunosuppression. Lancet 2020;395(10229):1033-1034

166 Dashti-Khavidaki S, Khalili H. Considerations for statin therapy in patients with COVID-19. Pharmacotherapy 2020;40(05): 484-486

167 Kong F, Ye B, Lin L, Cai X, Huang W, Huang Z. Atorvastatin suppresses NLRP3 inflammasome activation via TLR4/MyD88/ NF-KB signaling in PMA-stimulated THP-1 monocytes. Biomed Pharmacother 2016;82:167-172

168 Vandermeer ML, Thomas AR, Kamimoto L, et al. Association between use of statins and mortality among patients hospitalized with laboratory-confirmed influenza virus infections: a multistate study. J Infect Dis 2012;205(01):13-19

169 Yuan S. Statins may decrease the fatality rate of Middle East respiratory syndrome infection. MBio 2015;6(04):e01120

170 DeDiego ML, Nieto-Torres JL, Regla-Nava JA, et al. Inhibition of NF-кB-mediated inflammation in severe acute respiratory syndrome coronavirus-infected mice increases survival. J Virol 2014;88(02):913-924 
171 Violi F, Calvieri C, Ferro D, Pignatelli P. Statins as antithrombotic drugs. Circulation 2013;127(02):251-257

172 Glynn RJ, Danielson E, Fonseca FA, et al. A randomized trial of rosuvastatin in the prevention of venous thromboembolism. N Engl J Med 2009;360(18):1851-1861

173 Rosenson RS, Tangney CC. Antiatherothrombotic properties of statins: implications for cardiovascular event reduction. JAMA 1998;279(20):1643-1650

174 Chen G, Wu D, Guo W, et al. Clinical and immunological features of severe and moderate coronavirus disease 2019. J Clin Invest 2020;130(05):2620-2629

175 Magro C, Mulvey JJ, Berlin D, et al. Complement associated microvascular injury and thrombosis in the pathogenesis of severe COVID-19 infection: a report of five cases. Transl Res 2020:S1931-5244(20)30070-0

176 Stebbing J, Phelan A, Griffin I, et al. COVID-19: combining antiviral and anti-inflammatory treatments. Lancet Infect Dis 2020;20(04):400-402

177 Taylor PC, Weinblatt ME, Burmester GR, et al. Cardiovascular safety during treatment with baricitinib in rheumatoid arthritis. Arthritis Rheumatol 2019;71(07):1042-1055

178 National Institutes of Health Coronavirus Disease. 2019 (COVID19) Treatment Guidelines. Available at: https://www.covid19treatmentguidelines.nih.gov/. Accessed April 22, 2020

179 Genentech's arthritis drug tocilizumab shows promise in Covid19 trial. April 29, 2020. Available at: https://www.clinicaltrialsarena.com/news/french-early-trial-tocilizumab-covid-19/. Accessed May 14, 2020

180 Cummings MJ, Baldwin MR, Abrams D et al. Epidemiology, clinical course, and outcomes of critically ill adults with COVID-19 in New York City: a prospective cohort study. Lancet 2020;395(10239): 1763-1770

181 Richardson S, Hirsch JS, Narasimhan M, et al; and the Northwell COVID-19 Research Consortium. Presenting characteristics, comorbidities, and outcomes among 5700 patients hospitalized with COVID-19 in the New York City Area. JAMA 2020:e206775

182 Li J, Li Y, Yang B, et al. Low-molecular-weight heparin treatment for acute lung injury/acute respiratory distress syndrome: a meta-analysis of randomized controlled trials. Int J Clin Exp Med 2018;11(02):414-422
183 Ghezzi S, Cooper L, Rubio A, et al. Heparin prevents Zika virus induced-cytopathic effects in human neural progenitor cells. Antiviral Res 2017;140:13-17

184 Vicenzi E, Canducci F, Pinna D, et al. Coronaviridae and SARSassociated coronavirus strain HSR1. Emerg Infect Dis 2004;10 (03):413-418

185 Yin S, Huang M, Li D, Tang N. Difference of coagulation features between severe pneumonia induced by SARS-CoV2 and nonSARS-CoV2. J Thromb Thrombolysis 2020

186 Mycroft-West C, Su D, Elli S, et al. The 2019 coronavirus (SARSCoV-2) surface protein (Spike) S1 Receptor Binding Domain undergoes conformational change upon heparin binding. bioRxiv 2020: 2020.02.29.971093

187 Paranjpe I, Fuster V, Lala A, et al. Association of treatment dose anticoagulation with in-hospital survival among hospitalized patients with COVID-19. J Am Coll Cardiol 2020:S0735-1097(20) 35218-9

188 Lindhoff-Last E, Betz C, Bauersachs R. Use of a low-molecularweight heparinoid (danaparoid sodium) for continuous renal replacement therapy in intensive care patients. Clin Appl Thromb Hemost 2001;7(04):300-304

189 Chang JC. Acute respiratory distress syndrome as an organ phenotype of vascular microthrombotic disease: based on hemostatic theory and endothelial molecular pathogenesis. Clin Appl Thromb Hemost 2019;25:1076029619887437

190 Liu X, Li Z, Liu S, et al. Therapeutic effects of dipyridamole on COVID-19 patients with coagulation dysfunction. medRxiv 2020. Doi: 10.1101/2020.02.27.20027557

191 Sarangi PP, Lee HW, Kim M. Activated protein C action in inflammation. Br J Haematol 2010;148(06):817-833

192 Lu X, Chen T, Wang Wang, et al. Adjuvant corticosteroid therapy for critically ill patients with COVID-19. medRxiv 2020: 2020.04 . 07.20056390

193 Zhang Y, Xiao M, Zhang S, et al. Coagulopathy and antiphospholipid antibodies in patients with Covid-19. N Engl J Med 2020; 382(17):e38

194 Sun W, Li ZR, Shi ZC, Zhang NF, Zhang YC. Changes in coagulation and fibrinolysis of post-SARS osteonecrosis in a Chinese population. Int Orthop 2006;30(03):143-146 